\title{
AN EXAMINATION OF REBUILD AMERICA PARTNERSHIP ACCOMPLISHMENTS AND THE FACTORS INFLUENCING THEM
}

MARTIN SCHWEITZER

LAURA OGLE-GRAHAM

OAK RIDGE NATIONAL LABORATORY 


\title{
DOCUMENT AVAILABILITY
}

Reports produced after January 1,1996, are generally available free via the U.S. Department of Energy (DOE) Information Bridge.

Web site http://www.osti.gov/bridge

Reports produced before January 1, 1996, may be purchased by members of the public from the following source.

\author{
National Technical Information Service \\ 5285 Port Royal Road \\ Springfield, VA 22161 \\ Telephone 703-605-6000 (1-800-553-6847) \\ TDD 703-487-4639 \\ Fax 703-605-6900 \\ E-mail info@ntis.fedworld.gov \\ Web site http://www.ntis.gov/support/ordernowabout.htm
}

Reports are available to DOE employees, DOE contractors, Energy Technology Data Exchange (ETDE) representatives, and International Nuclear Information System (INIS) representatives from the following source.

Office of Scientific and Technical Information

P.O. Box 62

Oak Ridge, TN 37831

Telephone 865-576-8401

Fax 865-576-5728

E-mail reports@adonis.osti.gov

Web site http://www.osti.gov/contact.html

This report was prepared as an account of work sponsored by an agency of the United States Government. Neither the United States Government nor any agency thereof, nor any of their employees, makes any warranty, express or implied, or assumes any legal liability or responsibility for the accuracy, completeness, or usefulness of any information, apparatus, product, or process disclosed, or represents that its use would not infringe privately owned rights. Reference herein to any specific commercial product, process, or service by trade name, trademark, manufacturer, or otherwise, does not necessarily constitute or imply its endorsement, recommendation, or favoring by the United States Government or any agency thereof. The views and opinions of authors expressed herein do not necessarily state or reflect those of the United States Government or any agency thereof. 


\title{
AN EXAMINATION OF REBUILD AMERICA PARTNERSHIP ACCOMPLISHMENTS AND THE FACTORS INFLUENCING THEM
}

\author{
Martin Schweitzer and Laura Ogle-Graham
}

Date Published: September 2003

\author{
Prepared for \\ U.S. Department of Energy \\ Office of the Weatherization and Intergovernmental Program \\ Budget Activity Number EC 1504000 \\ Prepared by \\ OAK RIDGE NATIONAL LABORATORY \\ Oak Ridge, Tennessee 37831 \\ managed by \\ UT-BATTELLE, LLC \\ for the \\ U.S. DEPARTMENT OF ENERGY \\ under contract DE-AC05-00OR22725
}





\section{CONTENTS}

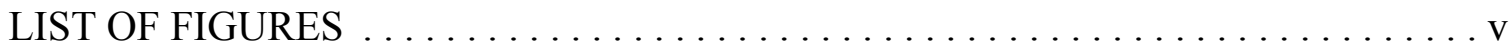

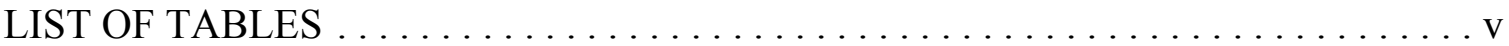

EXECUTIVE SUMMARY $\ldots \ldots \ldots \ldots \ldots \ldots \ldots \ldots \ldots \ldots \ldots \ldots \ldots \ldots$

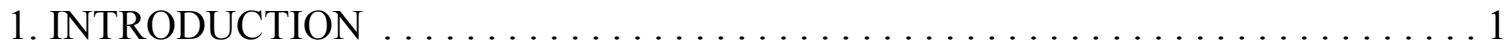

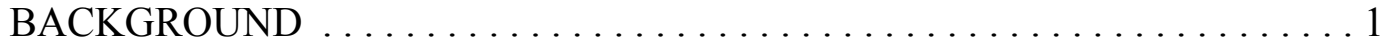

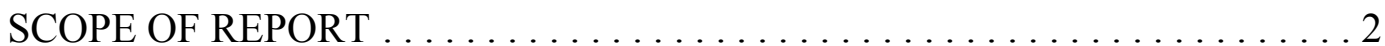

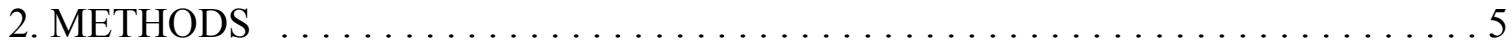

COLLECTION OF DESCRIPTIVE DATA ON PARTNERSHIP

CHARACTERISTICS AND PROJECT RESULTS $\ldots \ldots \ldots \ldots \ldots \ldots 5$

ANALYSIS OF POTENTIAL RELATIONSHIPS BETWEEN

PARTNERSHIP CHARACTERISTICS AND RESULTS . . . . . . 6

TELEPHONE INTERVIEWS WITH PARTNERSHIP

REPRESENTATIVES ......................8

3. DESCRIPTION OF PARTNERSHIP CHARACTERISTICS

AND RESULTS . . . . . . . . . . . . . . . . . . . . . . . . . . . 9

PARTNERSHIP CHARACTERISTICS . . . . . . . . . . . . . . . 9

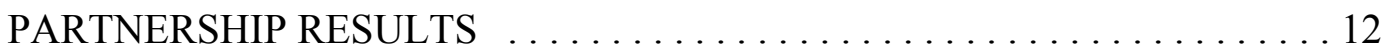

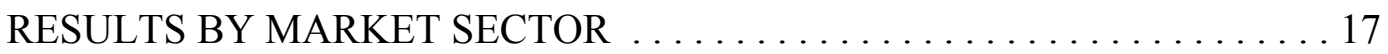

4. INFLUENCES ON PARTNERSHIP PERFORMANCE $\ldots \ldots \ldots \ldots \ldots \ldots \ldots .21$

STATISTICALLY SIGNIFICANT RELATIONSHIPS BETWEEN

SELECTED PARTNERSHIP CHARACTERISTICS

AND RESULTS . . . . . . . . . . . . . . . . . . . . . . . 21

PARTNERSHIP-REPORTED FACTORS RELATED TO GOOD

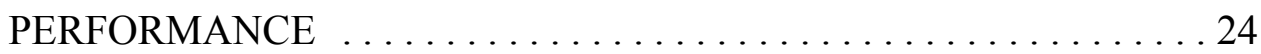

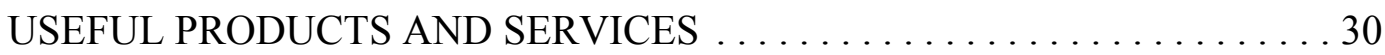

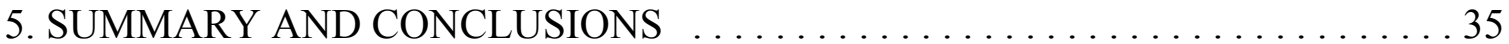

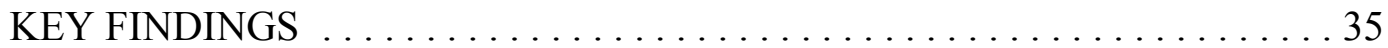

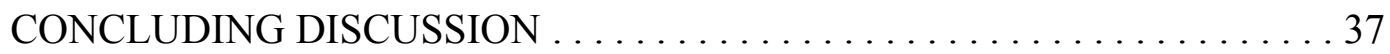

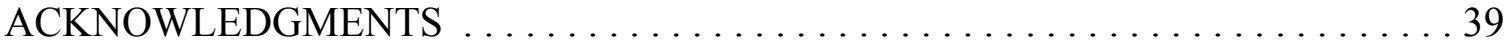

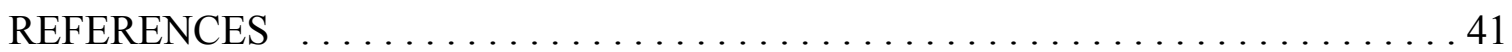




\section{LIST OF FIGURES}

Figure 1. Distribution of partnerships per state $\ldots \ldots \ldots \ldots \ldots \ldots \ldots \ldots \ldots \ldots \ldots \ldots \ldots$

Figure 2. Distribution of projects per partnership $\ldots \ldots \ldots \ldots \ldots \ldots \ldots \ldots \ldots$

Figure 3. Number of Rebuild America projects by market sector $\ldots \ldots \ldots \ldots \ldots 17$

\section{LIST OF TABLES}

Table 1. Selected characteristics of Rebuild America partnerships . . . . . . . . 10

Table 2. Rebuild America program results, by partnership . . . . . . . . . 14

Table 3. Cumulative results for all partnerships providing data $\ldots \ldots \ldots \ldots \ldots$

Table 4. Median project results, by market sector $\ldots \ldots \ldots \ldots \ldots \ldots \ldots \ldots \ldots$

Table 5. Cumulative project results, by market sector $\ldots \ldots \ldots \ldots \ldots \ldots \ldots$

Table 6. Relationships between partnership age and four key

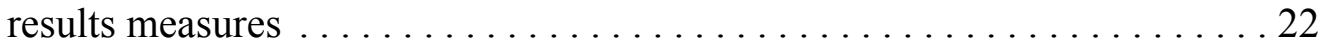

Table 7. Relationships between average office rent and four key

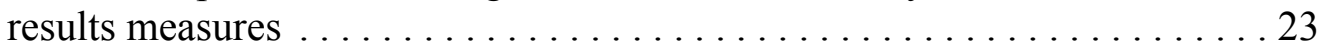

Table 8. Relationship between number of projects per partnership

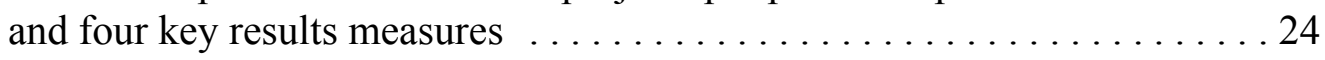

Table 9. Relationship between partnership age, number of projects

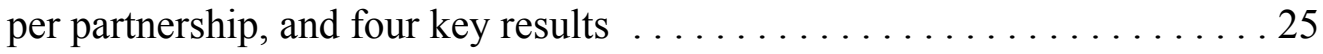

Table 10. Key factors influencing good performance, as reported by partnership representatives

Table 11. Most useful types of resources provided by Rebuild America, as reported by partnership representatives . . . . . . 30 


\section{EXECUTIVE SUMMARY}

\section{INTRODUCTION}

The Rebuild America program was established in 1994 to accelerate the adoption of energy efficiency measures and practices in existing public facilities, commercial buildings, and multifamily housing units. More recently, the program has expanded to include new construction as well. The program encourages the formation of partnerships involving state and local governments, private businesses, and other organizations to help identify and solve problems related to energy use in buildings. Rebuild America does not directly fund actual building improvements. Instead, it provides the Rebuild Partners with the technical tools and assistance they need to plan and implement building projects and stimulates other entities to make substantial investments in energy efficiency. At the request of the U.S. Department of Energy's Office of Energy Efficiency and Renewable Energy, staff at Oak Ridge National Laboratory studied the Rebuild America program for the purpose of identifying key factors associated with successful operations.

\section{METHODS}

Substantial amounts of data were collected directly from Rebuild America partnerships concerning the results achieved by each of their individual projects, both committed and completed. In addition, data were collected from secondary sources on a limited number of factors describing partnership setting and characteristics. By combining these two data sets, we were able to perform statistical analyses testing the potential relationship between each partnership characteristic and each of four key results measures.

The influences on successful partnership performance also were determined in another way, which allowed a broader examination of potentially important factors. Telephone interviews were conducted with representatives from 61 high-performing Rebuild America partnerships throughout the United States. The respondents were asked to identify the most important factors influencing good performance and the types of Rebuild America products, services, and support that were most useful to their partnership. In addition to having substantial geographic variation, the sample of partnerships also engaged in projects in all five sectors served by the Rebuild program-colleges and universities; commercial buildings; K-12 schools; local and state government; and public and multi-family housing - in roughly the same proportion as for the entire set of Rebuild America projects nationwide. 


\section{FINDINGS}

Two hundred fifty-eight partnerships provided data on the results achieved by a total of 899 Rebuild America projects (about three-fifths of them "committed" and twofifths completed) undertaken since the partnerships were formed. For all completed projects combined, the responding partnerships reported over half a billion square feet of floor space improvements, over 9 trillion source BTUs of annual energy savings, over $\$ 130$ million per year of cost savings, and more than \$600 million in energy efficiency investments. When committed projects were added to those that had already been completed, the combined results reported by all responding partnerships were between two and three times the size of those achieved by completed projects alone. Specifically, floor space improvements totaled over one billion square feet, annual energy and cost savings amounted to approximately 27 trillion source BTUs and $\$ 300$ million, respectively, and the energy efficiency investment exceeded $\$ 1.5$ billion.

According to the U.S. Department of Energy's recent Rebuild America 2002 report, every federal dollar spent on the Rebuild program from its inception through the end of 2002 generated $\$ 9.38$ of energy-efficiency investment and $\$ 18.43$ in cumulative energy cost savings over time. In addition, the current study shows that each dollar of program funding has resulted in nearly 8 square feet of floor space improvements, $\$ 1.95$ in annual cost savings, and annual energy savings of 0.134 million source BTUs from completed projects. For completed plus committed projects, each dollar of program funding is associated with over 16 square feet of floor space improvements, \$4.41 in annual cost savings, 0.396 million source BTUs of annual energy savings, and $\$ 22.35$ in energy efficiency investment.

It should be noted that all of the numbers reported above almost certainly undercount actual results because many Rebuild partnerships did not report their projects' accomplishments. In addition, the annual energy and cost savings reported here are for a single year only and can be expected to continue well into the future.

The greatest number of projects took place in the local and state government sector, followed by K-12 schools, commercial buildings, colleges/universities, and public/multi-family housing. Completed projects involving K-12 schools were far ahead of all the other sectors in terms of the median achievements for all results measures. For all projects (completed plus committed), K-12 schools reported the largest median values for the number of square feet renovated and energy efficiency investment, while colleges/universities led the way in terms of annual energy and cost savings.

Combined outcomes for all projects taken together depend on the number of projects carried out and the results achieved by each. The reported values were highest in K-12 schools for floor space improvements and in the local and state government sector for all other results measures. This applied both to completed projects and to all projects (completed plus committed). 
From the limited statistical analysis allowed by the available data, we found that partnership age and number of projects per partnership were both positively related to all the results measures that we tested, by themselves and in the presence of each other. This means that those partnerships that had been in existence the longest and had the greatest number of projects tended to have the largest area of floor space improvements and the greatest annual cost savings. Average office rent also was positively related to three of the four results measures tested, indicating that accomplishments were greatest in areas with higher property values. However, this latter finding is more questionable, because the number of respondents with the data necessary to run this analysis was quite small and was probably not representative of the entire population of Rebuild partnerships.

The factors most frequently mentioned by the interviewed partnership representatives as influencing good partnership performance were: general assistance from the Rebuild America representative; open communications among all partners; existence of a "champion" for the partnership; support from the relevant city or state government; effective marketing to attract new partners; strong community interest; quick return on investment; interaction with other community organizations; and continuity of funding. The types of Rebuild America resources that were most frequently mentioned as being most helpful were: tailored assistance from a Rebuild America representative; general technical support; workshops and training sessions; assistance with networking; peer exchanges and interactions; access to staff and resources at national laboratories; help with marketing the benefits of Rebuild America; educational materials; the Rebuild America website; links to national information sources; and financial support. In addition, many respondents commented on the importance of two particular subject areas addressed by those resources: potential energy-saving actions/opportunities and the savings potential of various actions.

The above-mentioned responses regarding the factors related to good performance and the most useful resources provided by the program indicate that Rebuild America is working as intended. In other words, the technical information, assistance, training, and peer exchanges provided through the community partnership structure lead to the increased use of energy-efficient technologies in targeted buildings.

We suggest the following possible activities for sustaining and building upon the past successes of the Rebuild America program:

- $\quad$ Keep providing individualized assistance, technical support, and training to partnerships, in a timely manner;

- Have the most effective Rebuild America representatives provide training on key topics to other state and regional Rebuild representatives;

- $\quad$ Ensure that sufficient informational materials are available regarding those sectors that are most frequently served and have yielded the greatest results;

- $\quad$ Facilitate peer-to-peer exchanges among Rebuild America partners; 
- $\quad$ Encourage active partnerships to stay in operation and take on additional projects;

- $\quad$ Encourage partnerships to report their activities; and

- Contact partnerships that are slow to complete projects-and possibly nonreporting partnerships as well—-to determine their needs for program assistance. 


\section{INTRODUCTION}

Under the sponsorship of the U.S. Department of Energy's Office of Energy Efficiency and Renewable Energy, staff at Oak Ridge National Laboratory (ORNL) studied the Rebuild America program for the purpose of identifying key factors associated with successful operations. This involved examining selected characteristics of the partnerships that participate in the Rebuild program, documenting the results they achieve, and searching for the most important influences on those results.

\section{BACKGROUND}

The Rebuild America program was established by the U.S. Department of Energy in 1994 to accelerate the adoption of energy efficiency measures and practices in existing public facilities, commercial buildings, and multifamily housing units (U.S. Department of Energy 2001). More recently, the program has expanded to include new construction as well. The program encourages the formation of partnerships involving state and local governments, private businesses, and other organizations to help identify and solve problems related to energy use in buildings. Rebuild America does not directly fund actual building improvements. Instead, it provides the Rebuild partners with the technical tools and assistance (e.g., handbooks, workshops, referrals to experts) necessary to plan and execute energy-efficient building projects that make use of innovative technologies and approaches (U.S. Department of Energy 1996). Each partnership chooses target buildings, establishes energy savings goals, seeks financing, and decides how to implement their project or projects (Powers 2000). Through these actions, a variety of entities (e.g., public housing authorities, private sector building owners) are stimulated to invest in energy efficiency.

As of early autumn 2002, there were 475 Rebuild America partnerships in existence. Using the data on partnership location provided by the Rebuild America website (U.S. Department of Energy 2002a), Figure 1 was developed to illustrate how the partnerships are distributed across the states. As shown in that figure, most states and territories contain a relatively small number of partnerships. Nearly half of the states (24) have only 1-5 partnerships operating within their borders, and over two-thirds (36) are home to 10 or fewer partnerships. On the other end of the scale, nearly one-tenth of the states and territories (5) have more than 25 Rebuild America partnerships. Those states with the highest number of partnerships are - in descending order-California, Texas, Idaho, Connecticut, and Ohio. 


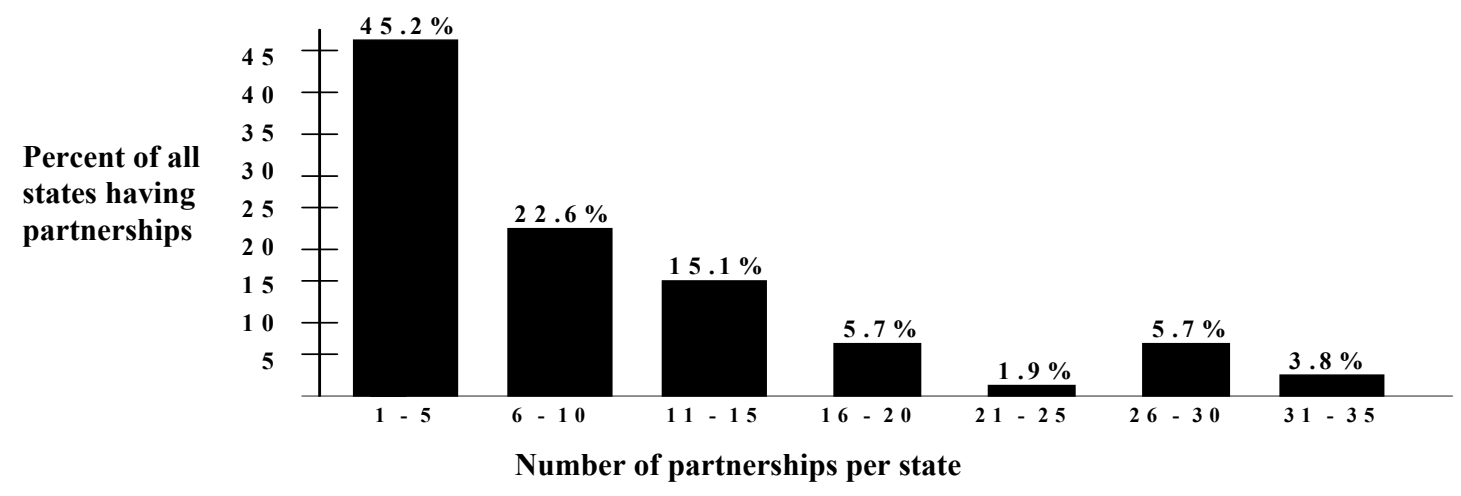

Fig. 1. Distribution of partnerships per state.

The term "program logic" refers to the intended process by which a program achieves its objectives. For Rebuild America, a simplified version of the program logic is as follows. Through the formation of community partnerships (and the establishment of business and strategic partners), key actors in the institutional, commercial, and multifamily residential building sectors are brought together and important information on energy-efficient products and techniques is disseminated to the relevant parties. Assistance and training from technical experts are provided to the parties needing it, and help with key decisions is provided through peer exchanges of information and advice. Through this process, appropriate projects are identified, financing is arranged, resources are invested, and technical issues are resolved. This in turn leads to the increased use of energy-efficient technologies, the increased availability of relevant products, and the accelerated adoption of energy-efficient measures and practices. Ultimately, the building improvements carried out under the program result in energy and cost savings for program participants and environmental benefits for the larger society.

\section{SCOPE OF REPORT}

Subsequent chapters of this report discuss the research methods employed in the ORNL study and the key findings of that effort. Chapter 2 presents the methods used, focusing on the collection of descriptive data, the statistical analysis of potential relationships between partnership characteristics and results, and the direct solicitation of information from partnership representatives on the factors that influence performance. In Chapter 3, we describe selected partnership characteristics and provide a detailed description of the key results achieved, both by partnership and by market sector. Chapter 4 discusses what this study shows about the factors influencing good partnership 
performance and about the most useful products and services provided by the Rebuild America program. Finally, Chapter 5 summarizes the key findings reported earlier and reflects on their implications. 


\section{METHODS}

The research plan for this project called for ORNL staff to collect data directly from Rebuild America partnerships on relevant organizational and contextual characteristics and on key project accomplishments and to gather additional data from secondary sources on other important partnership attributes. These data would then be used to perform a quantitative analysis designed to identify relationships between important partnership features and the results achieved. To supplement any findings that might result from the statistical analysis, a substantial number of telephone interviews were conducted with representatives of partnerships from all over the country; the respondents were asked to describe what they believed to be the most important factors influencing good performance by a partnership and the most useful products and services provided by the Rebuild America program. Each of the broad methodological areas described above is discussed in more detail in the following sections.

\section{COLLECTION OF DESCRIPTIVE DATA ON PARTNERSHIP CHARACTERISTICS AND PROJECT RESULTS}

ORNL staff developed a data collection instrument to elicit information directly from Rebuild America partnerships on about a dozen key factors related to community setting, supporting resources, and partnership composition, priorities, and dynamics. This instrument (called the "Partnership Description") was posted on the Rebuild America website in October 2002 and partnership representatives were contacted and asked to provide the requested information. Unfortunately, only nine partnerships provided the requested data, and this number of responses was far too low to allow the type of statistical analysis that had originally been planned ${ }^{1}$.

As part of the online data collection effort discussed above, the partnerships also were asked to provide information on the results achieved by each of their individual projects, both committed and completed. The questions on project results represented a continuation of a periodic reporting exercise that had been conducted for several years. The following results data were requested for each project undertaken since the partnership was formed: (1) number of square feet of floor space improvements;

(2) annual energy savings (in million source BTUs) resulting from the actions taken;

(3) annual cost savings (in dollars) associated with those actions; and (4) energy efficiency investment (in dollars) induced by the program. At a minimum,

\footnotetext{
${ }^{1}$ Not only was the number of respondents too low for the planned analysis, but it was considered highly unlikely that those nine partnerships were representative of the entire population of Rebuild America participants.
} 
respondents were required to provide data on square feet renovated, annual cost savings, or energy efficiency investment, with any missing values calculated by Rebuild America based on the data provided. As of early March 2003, 258 Rebuild America partnerships had reported results data on 899 projects-369 completed and 530 committed. From this data set, we were able to create two new variables: the number of projects completed by each partnership and the number of all projects (completed plus committed) associated with each partnership.

Information on a limited number of factors describing partnership settings and characteristics was gathered from secondary data sources. Partnership age was calculated for all 475 partnerships that were in existence as of early autumn 2002, using information provided on the Rebuild America website (U.S. Department of Energy 2002a) regarding when each partnership joined the program. Data on the number of heating and cooling degree days was available from the National Oceanic and Atmospheric Administration for 473 of the partnerships. In about two-thirds of the cases, those data were available for the city in which the partnership was headquartered or for a nearby municipality (National Climatic Data Center 2002a and 2002b). In the remaining instances, state-level information was used because that was the best available (National Climatic Data Center 1993a and 1993b). Average energy cost data were gathered for 469 partnerships from the U.S. Energy Information Administration's State Energy Price and Expenditure Report 1999 (November 2001). Those data describe average energy $\operatorname{cost}^{2}$ for the state in which the partnership is located, but not for the specific county or municipality. Finally, data on the average rent paid for office space was obtained from a private sector real estate research company (Reis, Inc. 2002) for 50 major metropolitan regions covering 102 of the Rebuild partnerships.

The collection of secondary data and the new variables on number of projects per partnership, in conjunction with the primary data on project results, allowed us to perform statistical analyses aimed at discovering relationships between selected factors and partnership accomplishments. However, the scope of this analysis was much more limited than it would have been if an adequate number of partnerships had provided the requested Partnership Description data.

\section{ANALYSIS OF POTENTIAL RELATIONSHIPS BETWEEN PARTNERSHIP CHARACTERISTICS AND RESULTS}

In the design stage of this study, a set of hypotheses was developed showing all the potential relationships to be tested between partnership characteristics and results. Later, after seeing the large number of single-project partnerships, we added a new hypothesis regarding the effect of the number of projects on partnership performance. As noted above, a substantial number of partnerships provided primary data on the results

\footnotetext{
${ }^{2}$ The average cost reported here represents a weighted average of all energy-consuming sectors.
} 
achieved by their project efforts. However, only a few partnerships provided the detailed information requested by the Partnership Description instrument. Accordingly, we were able to test only the following six hypotheses, which utilize the project results data and information on partnership characteristics that were available from secondary sources:

- Age of Partnership is positively related to performance;

- Number of heating degree days in local area (or state) is related to performance;

- Number of cooling degree days in local area (or state) is related to performance;

- Average energy cost in state is positively related to performance;

- Average asking rent for office space in local area is related to performance; and

- Number of projects per partnership is positively related to performance.

Partnership performance was represented by four separate results measures: (1) completed square feet of floor space improvements; (2) completed plus committed square feet of floor space improvements; (3) annual completed cost savings; and (4) annual completed plus committed cost savings. These variables were chosen for study because improved square footage and cost savings are the results that are most commonly reported by responding partnerships. And because all the results measures are highly correlated with each other, it was considered unnecessary to use each individual measure in the analysis. Results for completed projects were separated from the results associated with all projects (completed plus committed) to allow a more thorough testing of each hypothesized relationship.

Simple regression analysis was used to test the potential relationship between each partnership characteristic (the independent variable) and each of the results measures described above (the dependent variable). In other words, a regression analysis was run to see how partnership age was related to completed square feet renovated, and separate analyses were run to see how that same independent variable was related to total square feet, completed cost savings, and total cost savings. The same procedure was repeated for each of the other independent variables. For five of the six characteristics tested, data from over 250 partnerships were used in each analysis. However, for the tests involving average office rent, only 48 partnerships had non-missing values for both the independent and dependent variables required to run the statistical analysis.

Multiple regression analyses also were run to see how each dependent variable was related to the combined set of independent variables that were found to be significant via simple regression. However, those multiple regression results are only considered reliable when the number of partnerships with non-missing values for the entire set of independent variables remains relatively high. If the data set used in the analysis becomes too small, it cannot be considered representative of the entire population of Rebuild America partnerships, and the nature and strength of any relationships indicated by those analyses are likely to be misleading. In such instances, the multiple regression results are not reported here. 


\section{TELEPHONE INTERVIEWS WITH PARTNERSHIP REPRESENTATIVES}

Telephone interviews were conducted with representatives from 61 Rebuild America partnerships throughout the United States. Because a major focus of the interviews was on identifying the key factors associated with good performance, it followed that the partnerships selected for this study should all be high performers. Using results data provided by 258 partnerships, ORNL staff compiled a list of those reporting the largest amount of floor space (completed and committed together) that had been improved under the program. This set of high achieving partnerships served as our sampling frame (i.e., the set of subjects from which we selected the sample).

The Rebuild America program provides services to buildings in five different sectors: colleges and universities; commercial buildings; K-12 schools; local and state government; and public and multi-family housing (U.S. Department of Energy 2002b). To ensure a representative sample, we made sure that the proportion of projects in each sector was approximately the same for the sample of partnerships that we selected as for the entire set of Rebuild America projects nationwide. We also took care to achieve a good geographic mix. Once the prospective sample partnerships were identified, they were divided into six separate sets — one for each Rebuild America region-and the appropriate list was sent to each Rebuild America regional team leader for his or her review. The team leaders examined the lists, suggested deletions and additions as necessary, and provided contact names and telephone numbers for the partnerships contained in the final lists.

The final sample contained 83 partnerships, and interviews were completed with 61 of them. Of those 61 partnerships, 25 conducted projects in the local and state government market sector, 19 in the K-12 schools sector, 15 in the commercial buildings sector, 13 in the college and university sector, and 12 in the public and multi-family housing sector. The combined number of projects exceeds the number of partnerships interviewed because some partnerships conducted projects in multiple sectors.

A set of open-ended questions was developed for the interviews. ${ }^{3}$ Several of the questions were designed to collect background data on the partnerships and how they operated. For the purposes of this study, the key questions asked respondents to identify the most important factors influencing good performance and the types of Rebuild America products, services, and support that were most useful to their partnership. The typical interview took 20 to 45 minutes to complete, and all of them were performed between October 2002 and February 2003.

3 These open-ended questions were substantially different than the more tightly-structured items used in the online data collection effort and, for the most part, they covered different topics. The data collected through the interviews, which came from a non-random sample of highly successful partnerships, were not used in the statistical analyses discussed previously. 


\section{DESCRIPTION OF PARTNERSHIP CHARACTERISTICS AND RESULTS}

This chapter presents descriptive data on several relevant characteristics of Rebuild America partnerships and on the key results achieved by those partnerships. In addition, program results are disaggregated by market sector (e.g., K-12 schools, commercial buildings) and the achievements of the various market sectors are compared.

\section{PARTNERSHIP CHARACTERISTICS}

As noted earlier, ORNL staff collected data from secondary sources for a statistical analysis designed to uncover relationships between the magnitude of the results achieved by Rebuild America partnerships and selected characteristics of those partnerships and the environment in which they operate. The characteristics examined were: partnership age; number of heating and cooling degree days in the area served by the partnership; average energy cost; and average office rent. In addition, the number of projects per partnership was calculated from the project-level data provided by 258 partnerships. Each of these topics is discussed separately below. The secondary data presented here were collected in early autumn of 2002, at which time there were 475 partnerships participating in the Rebuild America program. The information on number of projects per partnership comes from a data set that was current as of early March 2003.

\section{Partnership Age}

The age of each of the 475 partnerships - as of October 1, 2002-was determined based on the date that it joined the Rebuild America program. The age of the partnerships ranged from 0.1 to 7.4 years, with a median age (i.e., half the partnerships were younger and half were older) of 2.75 years. The interquartile range (i.e., the "middle half" of the respondents, falling between the $25^{\text {th }}$ and $75^{\text {th }}$ percentiles) was 1.4 to 4.6 years (Table 1 ).

\section{Heating and Cooling Degree Days}

The number of heating degree days in the areas served by the various partnerships ranged from a minimum of 0 in the Virgin Islands and Hawaii to a maximum of 10,470.0 in Alaska, with a median value of 4634.0. The interquartile range was 2663.3 to 5960.8 . Cooling degree days ranged from 3.0 in Alaska to 5,256.7 in the Virgin Islands, with the median (998.0) falling toward the lower end of the scale and an interquartile range of 714.0 to 1801.2 . 
Table 1. Selected characteristics of Rebuild America partnerships

\begin{tabular}{|c|c|c|c|c|c|}
\hline & $\begin{array}{l}\text { Number of } \\
\text { partnerships } \\
\text { for which data } \\
\text { are available }\end{array}$ & $\begin{array}{l}\text { Minimum } \\
\text { value }\end{array}$ & $\begin{array}{c}\text { Maximum } \\
\text { value }\end{array}$ & $\begin{array}{l}\text { Median } \\
\text { value }\end{array}$ & $\begin{array}{c}\text { Interquartile } \\
\text { range }\end{array}$ \\
\hline Partnership age $^{a}$ & 475 & 0.11 & 7.42 & 2.75 & $1.39-4.59$ \\
\hline Heating degree days $b$ & 473 & 0 & $10,470.00$ & 4634.0 & $\begin{array}{c}2663.3- \\
5960.8\end{array}$ \\
\hline Cooling degree days ${ }^{b}$ & 473 & 3.00 & $5,256.70$ & 998.0 & $\begin{array}{l}714.0- \\
1801.2\end{array}$ \\
\hline $\begin{array}{l}\text { Average energy cost }{ }^{c} \\
\text { (\$ per million site } \\
\text { BTUs) }\end{array}$ & 469 & 5.77 & 13.23 & 8.63 & $7.64-9.89$ \\
\hline $\begin{array}{l}\text { Average office rent }{ }^{d} \\
\text { (\$ per square foot per } \\
\text { year) }\end{array}$ & 102 & 15.13 & 46.80 & 22.71 & $19.56-26.92$ \\
\hline $\begin{array}{l}\text { Number of completed } \\
\text { projects per } \\
\text { partnership }^{e}\end{array}$ & 258 & 0 & 19 & 1 & $0-1$ \\
\hline $\begin{array}{l}\text { Number of completed } \\
\text { plus committed projects } \\
\text { per partnership }^{\mathrm{f}}\end{array}$ & 258 & 1 & 41 & 1 & $1-3$ \\
\hline \multicolumn{6}{|c|}{$\begin{array}{l}{ }^{a} \text { Age of partnership as of 10/01/02, based on "Date Joined" as listed on Rebuild America Website. } \\
{ }^{b} \text { Heating and cooling degree day data provided by National Oceanic and Atmosphere Administration }\end{array}$} \\
\hline
\end{tabular}




\section{$\underline{\text { Average Energy Cost }}$}

Information on average state-level energy costs was available for 469 partnerships. According to the available data, average energy costs ranged from $\$ 5.77$ to $\$ 13.23$ per million site BTUs. The median value was $\$ 8.63$ and there was a fairly tight interquartile range (\$7.64 to $\$ 9.89$ ).

\section{Average Rent for Office Space}

Data on the average rent for office space were available for only 102 of the 475 partnerships ${ }^{4}$. For those partnerships, average office rents ranged from $\$ 15.13$ to $\$ 46.80$ per square foot per year. The median was $\$ 22.71$, placing it near the low end of the continuum, and the interquartile range was $\$ 19.56$ to $\$ 26.92$.

\section{Number of Projects per Partnership}

Two hundred fifty-eight partnerships supplied data on their number of projects. The minimum number of projects completed per partnership was zero, and the maximum was 19 . The median value was 1 , and the interquartile range was extremely narrow (0 to 1). Over $41 \%$ of the responding partnerships had not yet completed any projects, and another $34 \%$ had completed only one. An additional $10 \%$ of the partnerships had completed two projects, with $8 \%$ reporting 3-5 completed projects. Only $6 \%$ of the partnerships had completed 6 or more projects. A statistical analysis revealed that the number of completed projects was significantly positively correlated with the age of the partnership $(r=0.1944 ; p=.002)$. This means that partnerships that had been in existence longer tended to have completed a greater number of projects.

For all projects (completed plus committed), the minimum number was 1 per partnership and the maximum was 41 . The median value was 1 and the interquartile range was $1-3$. Nearly $52 \%$ of the partnerships had only a single project, almost $17 \%$ had two projects, and another $10 \%$ had 3 projects. Over $7 \%$ of the partnerships reported having 4 or 5 projects. A little more than $6 \%$ of the partnerships had 6-10 projects, and about $5 \%$ reported having 11-20 projects. That leaves a very small number of partnerships (less than 3\%) with more than 20 partnerships each (Figure 2). The number of completed plus committed projects was not significantly correlated with partnership age. Since the number of completed projects was found to increase with partnership age, this finding indicates that the number of committed projects did not increase significantly over time.

\footnotetext{
${ }^{4}$ The available data covered only 50 major metropolitan regions, in which 102 Rebuild America partnerships were located.
} 


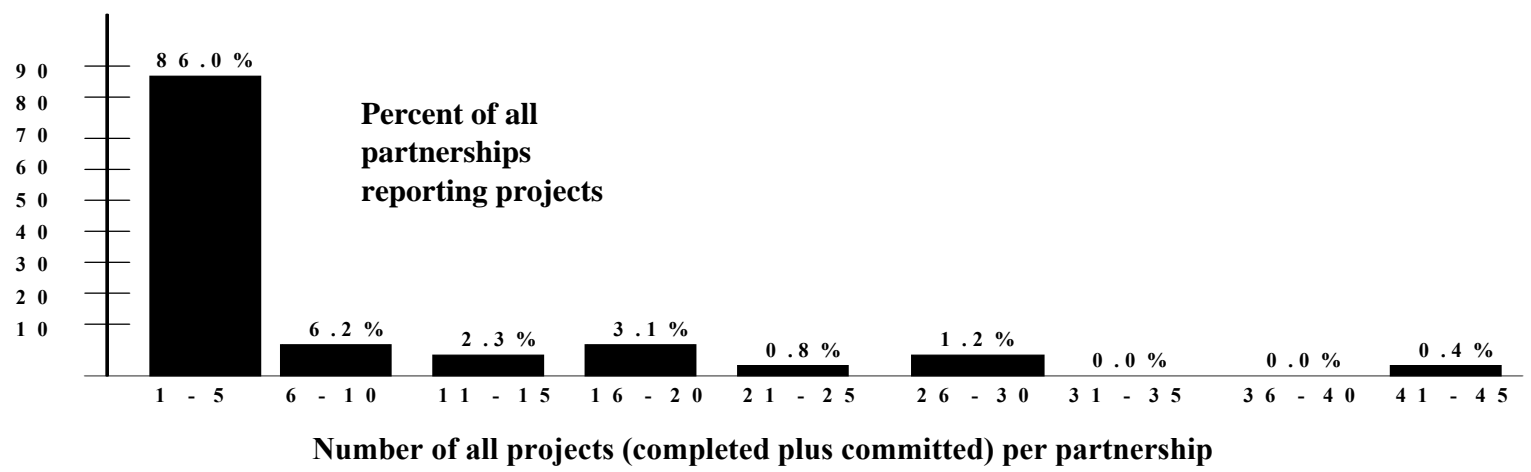

Fig. 2. Distribution of completed plus committed projects per partnership.

\section{PARTNERSHIP RESULTS}

As of early 2003, 258 partnerships had provided data to the program sponsors on the results achieved by their Rebuild America projects. It is important to note that over 200 partnerships did not respond to the request to report their project accomplishments, meaning that the numbers presented below almost certainly undercount actual results. Among them, the 258 responding partnerships supplied information on 899 separate projects undertaken since the partnerships were formed. Each project reported by a partnership was described as either "committed" or "completed." "Committed" projects can be in various stages of planning or implementation short of total completion.

Information was provided on four different results for each project: the size of the improved area (in square feet); annual energy savings achieved or anticipated (in million source BTUs); annual cost savings (in dollars); and energy efficiency investment (also in dollars). For each partnership having multiple projects, the project-specific information provided was summed to give a single number for each type of result (e.g., total committed square feet for that partnership, total completed energy efficiency investment for that partnership). The findings for each results measure are discussed separately below. Median values are reported for all partnerships as well as for the subset of partnerships that had been in existence for at least two years. That subset of more mature partnerships excludes many of those that had not yet had time to bring their projects to completion. Results also are reported for all partnerships combined, and those numbers are consistent with the findings contained in the U.S. Department of Energy's recent Rebuild America 2002 report (2003), which documents the program's accomplishments. ${ }^{5}$

\footnotetext{
5 Any differences between the numbers reported here and those given in the Department of Energy report tend to be relatively small and are due to the fact that this document is based on slightly newer data.
} 


\section{Floor Space Improvements}

The number of completed square feet of floor space improvements ranged from zero to over 100 million per partnership (Table 2). The median area of completed floor space improvements (which is greater than the values reported by half of the partnerships and less than the values reported by the other half) was slightly less than 24,000 square feet $^{6}$ per partnership. However, when those partnerships that had been in existence for less than two years were removed from the data set, the median value jumped to almost 85,000 square feet per partnership, indicating that it takes a certain amount of time for new partnerships to start completing their planned projects. The interquartile range (covering the $25^{\text {th }}$ to $75^{\text {th }}$ percentiles) extended from zero to 722,200 square feet. Approximately 45 percent of the partnerships (116 out of 258) had zero square feet of floor space improvements completed at the time they reported their results. At the other extreme, there were a few partnerships that completed projects covering millions of square feet, but those were relatively uncommon. The combined completed floor space improvements for all reporting partnerships, as shown in Table 3, was over half a billion.

The area of floor space improvements for completed plus committed projects ranged from zero to nearly 115 million square feet per partnership, with a median value of approximately 580,000 square feet for the entire set of partnerships and 830,000 square feet for those partnerships that had been in existence for at least two years (Table 2). These median value are much higher than for the completed area because many partnerships have significant amounts of committed floor space improvements as part of ongoing projects. The interquartile range was 86,000 to 2.2 million square feet, once again substantially higher than for completed projects alone. The combined number of total square feet (committed plus completed) for all responding partnerships was slightly over one billion (Table 3).

\section{Energy Savings}

As shown in Table 2, the annual energy savings associated with completed projects ranged from zero to over two trillion source BTUs per partnership, with a median value of 345 million source BTUs. For partnerships that were at least two years old, the median value almost tripled, to 992 million source BTUs. The interquartile range extended from zero to just under nine billion source BTUs. As with square footage, approximately 45 percent of the partnerships reported zero savings for completed projects, while a few

\footnotetext{
${ }^{6}$ Because a few partnerships reported extremely large numbers for this results measure (and the other results measures as well), medians are used here as a more accurate measure of central tendency than means. The mean number of completed square feet of floor space improvements, for example, is over two million, which is well outside the interquartile range and is clearly skewed.
} 


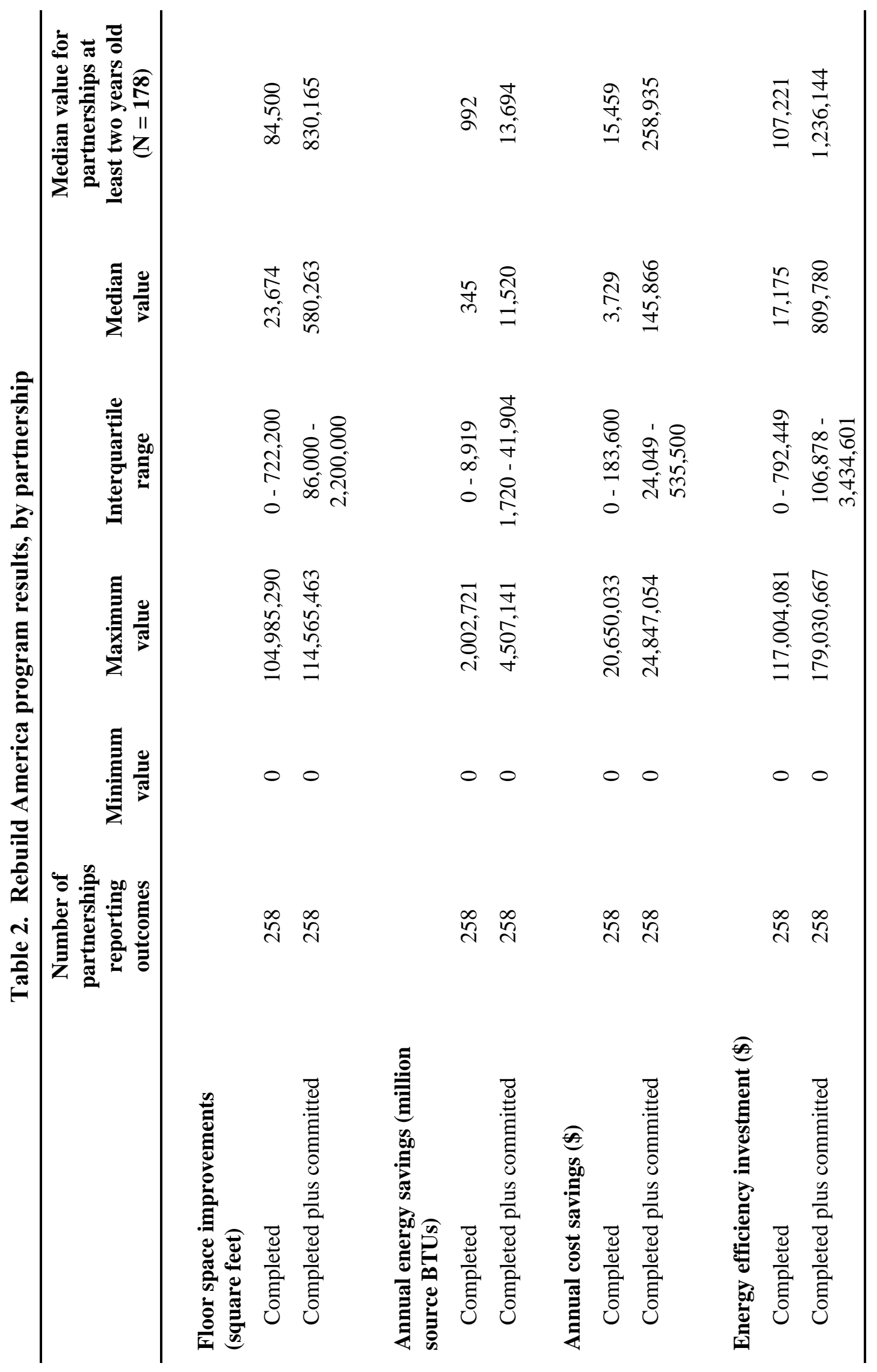


Table 3. Combined results for all partnerships providing data

Floor space improvements (square feet)

Completed

Completed plus committed
Combined total results

$528,290,864$

$1,097,454,870$

\section{Annual energy savings (million source}

BTUs)

Completed

$9,096,515$

Completed plus committed

$26,984,032$

\section{Annual cost savings (\$)}

Completed

$132,947,399$

Completed plus committed

$300,642,672$

\section{Energy efficiency investment (\$)}

Completed

$605,189,919$

Completed plus committed

$1,522,019,622$

partnerships had achieved extremely high savings. Altogether, the responding partnerships reported combined annual energy savings of over nine trillion source BTUs from their completed projects (Table 3). These annual energy savings—as well as the energy and cost savings discussed below—are expected to continue for many years.

Annual energy savings achieved by completed plus committed projects ranged from zero to 4.5 trillion source BTUs per partnership, with a median value of approximately 11.5 billion source BTUs for the full set of for partnerships and 13.7 billion BTUs for those partnerships that were at least two years old (Table 2). As with floor space improvements, the median is much higher than for completed savings due to the substantial savings associated with committed projects. The interquartile range extended from slightly less than two billion source BTUs to nearly 42 billion source BTUs annually. Again, this is substantially higher than for completed projects alone. As Table 3 shows, the combined amount of energy savings reported for all projects (completed plus committed) totaled nearly 27 trillion source BTUs per year. 


\section{Cost Savings}

Table 2 shows that the annual cost savings for completed projects ranged from zero to over $\$ 20$ million per partnership. The median value for completed savings was slightly less than $\$ 4,000$ per partnership for the entire data set but over $\$ 15,000$ for partnerships that had been formed at least two years previously. The interquartile range extended from zero to nearly $\$ 184,000$. Once more, about 45 percent of the partnerships reported zero savings from completed projects, in contrast to a few partnerships that achieved enormous cost savings. As a group, the responding partnerships reported combined cost savings of almost $\$ 133$ million annually from their completed projects (Table 3).

Annual cost savings for completed plus committed projects ranged from zero to nearly $\$ 25$ million, with a median value of almost $\$ 146,000$ for the entire set of responding partnerships and almost $\$ 260,000$ for the subset of more mature partnerships (Table 2). Again, the median value is much higher than for completed savings because of the substantial savings contributed by committed projects. The interquartile range ran from a little less than $\$ 25,000$ to slightly more than $\$ 535,000$. For all projects combined, completed plus committed cost savings totaled over $\$ 300$ million annually (Table 3).

\section{Energy Efficiency Investment}

While the Rebuild America program does not directly fund building improvements, it does stimulate other entities (e.g., school districts, state and local government agencies, private sector building owners and mangers) to make substantial investments in energy efficiency. The energy efficiency investment for completed projects ranged from zero to approximately $\$ 117$ million per partnership, with a median value of just over $\$ 17,000$ for the full data set and $\$ 107,000$ for the subset of partnerships that had been in existence for at least two years (Table 2). The interquartile range was zero to almost $\$ 800,000$. As with all the other results measures, roughly 45 percent of the partnerships reported zero investment for completed projects. Table 3 shows that the combined energy efficiency investment associated with all completed projects amounted to over $\$ 600$ million.

The energy efficiency investment for all projects (completed plus committed) ranged from zero to almost $\$ 180$ million per partnership, with a median value of over $\$ 800,000$ for all partnerships and more than $\$ 1.2$ million for the subset of older partnerships (Table 2). As always, this median value is substantially higher than for completed projects alone because of the substantial investment in committed projects. The interquartile range ran from almost $\$ 107,000$ to over $\$ 3.4$ million. The total energy efficiency investment for all completed and committed projects combined amounted to over $\$ 1.5$ billion (Table 3 ). 


\section{RESULTS BY MARKET SECTOR}

As noted above, data were provided by the responding partnerships on 899 separate projects, 369 of which were described as "completed" and 530 of which were classified as "committed." The market sector addressed by each project was specified. In the following sections, the number of projects, their median results, ${ }^{6}$ and the combined results are compared for the five different sectors served by the Rebuild program.

\section{Number of Projects}

Figure 3 shows how the reported projects were distributed among the five market sectors. There were more projects involving local and state government buildings than any other type of structure, with this sector accounted for slightly more than two-fifths of the completed projects and over one-third of all projects (completed plus committed). There also was substantial activity in K-12 schools, where more than one-fifth of the completed projects and about the same proportion of all projects (completed plus committed) took place. Slightly less than one-fifth of all projects (completed plus committed) and about one-seventh of the completed projects involved commercial buildings. Roughly one-eighth of the projects took place in the colleges and universities sector, and a slightly smaller proportion of the projects involved public and multi-family housing. Although there was less activity in these last two areas than in the others, the responding partnerships still demonstrated considerable interest in them.

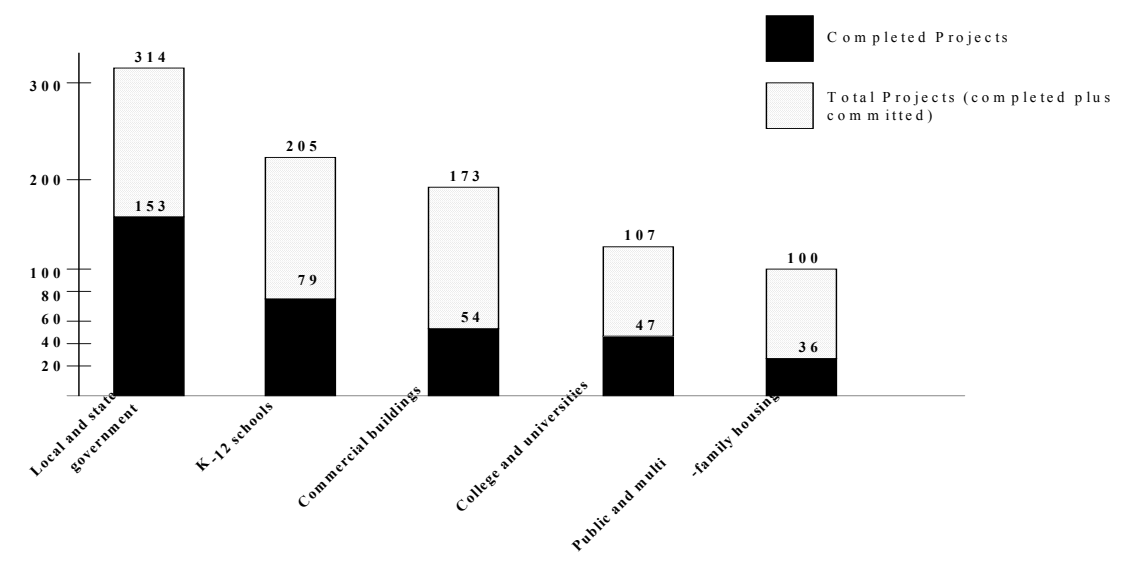

Figure 3. Number of Rebuild America projects by market sector.

\footnotetext{
${ }^{6}$ The median values for completed projects tend to be substantially higher than for partnerships. This is because partnerships typically only reported a project as completed if there were non-zero values for the results measures. However, when we compiled the partnerships data base, we recorded zero completed results values for projects that were reported as committed but not yet complete, and this had the effect of deflating the median values.
} 


\section{Median Project Results}

As shown in Table 4, completed projects involving K-12 schools led all the other sectors in terms of the median area of floor space improvements $(249,000$ square feet), annual energy savings ( 4.5 billion source BTUs), annual cost savings (nearly $\$ 48,000$ ), and energy efficiency investment (just over \$240,000). In fact, for all of those measures, the numbers reported for the K-12 schools sector were at least twice those for the nextThe median values for completed projects tend to be substantially higher than for partnerships. closest sector. For completed floor space improvements and energy savings, the second highest median values were found in colleges and universities, followed by commercial buildings, local and state government, and public and multi-family housing, in that order. The order of the sectors ranked second to fifth differs somewhat for completed cost savings and energy efficiency investment.

For all projects (completed plus committed), the K-12 schools sector still reported larger median values for the number of square feet renovated (approximately 225,000) and energy efficiency investment (nearly $\$ 300,000$ ) than any other sector. For both of those measures, colleges and universities had the second-highest median values, followed by local and state government, public and multi-family housing, and commercial buildings. For both energy and cost savings, the largest median values were found in college and university buildings (5.2 billion source BTUs and nearly $\$ 53,000$ annually), followed by K-12 schools, local and state government, public and multi-family housing, and commercial buildings.

\section{Combined Project Results}

The accomplishments of all projects combined are dependent on the number of projects carried out and the magnitude of the results achieved by each one. For that reason, it makes sense that those sectors with the most projects would tend to have high combined numbers, as would those sectors where the median results are greatest. As shown in Table 5, the highest combined value for completed floor space improvements (over 187 million square feet) is in the K-12 schools sector and the greatest combined values for completed energy savings (4.6 trillion source BTUs annually), cost savings (nearly \$44 million per year), and energy efficiency investment (over \$230 million) are all in the local and state government sector. It should also be noted that a few exceptionally high values can dramatically raise the combined value of a project result, even if the median value is relatively low.

For all projects (completed plus committed), the rank order of the sectors for each results measure is largely the same as for completed projects (Table 5). The few differences between completed projects and completed plus committed projects in the relative ranking of the sectors can largely be explained by the achievement of extremely large results by a small number of partnerships (e.g., exceptional completed plus committed energy savings by one partnership in the colleges and universities sector). 


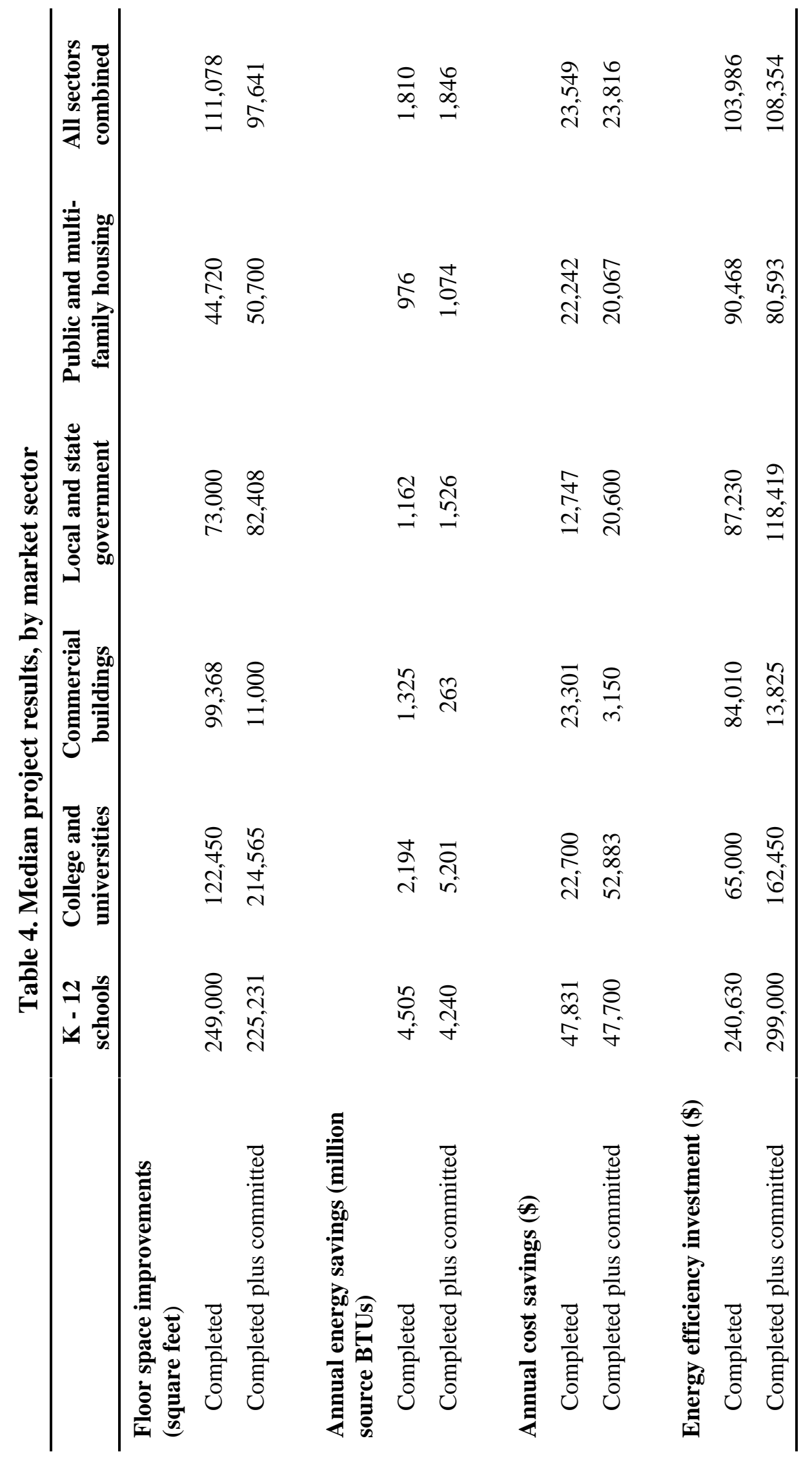




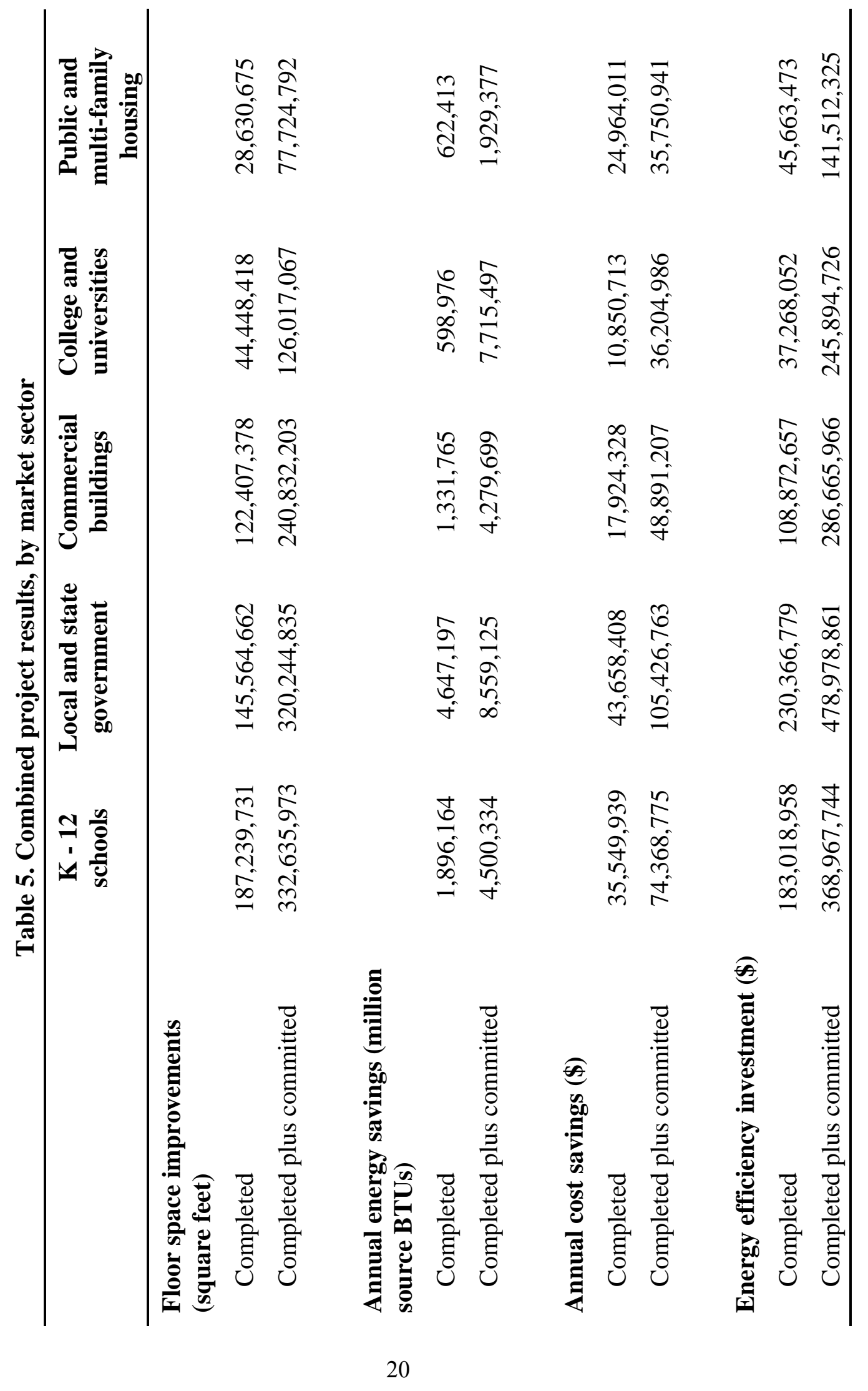




\section{INFLUENCES ON PARTNERSHIP PERFORMANCE}

The search for factors that influence partnership performance involved two distinct efforts: (1) performing a quantitative analysis of the relationships between key results and those characteristics of the partnerships and their environment for which good information was available; and (2) soliciting opinion data from partnership representatives regarding the factors related to good performance and the most useful products and services provided by the Rebuild America program. The key findings from those efforts are reported in separate sections, below.

\section{STATISTICALLY SIGNIFICANT RELATIONSHIPS BETWEEN SELECTED PARTNERSHIP CHARACTERISTICS AND RESULTS}

A statistical analysis was performed to test possible relationships between selected partnership characteristics and key results ${ }^{7}$. Three of the six characteristics tested-age of partnership, average office rent, and number of projects per partnership - were found to have statistically significant relationships with all or most of the results measures used in the analysis, and these are discussed in more detail below. For the other three characteristics- - heating degree days, cooling degree days, and average energy cost—no significant relationship with the results measures were found.

\section{Age of Partnership}

Table 6 shows that partnership age was positively related to all the results measures analyzed: completed square feet of floor space improvements; completed plus committed floor space improvements; completed cost savings, and completed plus committed cost savings. This means that all of those results tended to be greater for partnerships that had been in existence for longer periods of time, which makes sense because older partnerships have had more time to initiate and complete energy-saving projects and to gather the resources and expertise necessary for high performance. For all of the results measures, the relationship with partnership age was highly significant $(\mathrm{p}<.0001)$, meaning that it is extremely likely that this relationship applies to the entire population of Rebuild America partnerships and not just to those that provided data for

${ }^{7}$ As described in Chapter 2, a simple regression analysis was run for each partnership characteristic (the independent variable) with each of the key results measures (the dependent variable). Multiple regression analyses also were run for each dependent variable with the combined set of independent variables found to be significant via simple regression. 
Table 6. Relationships between partnership age and four key results measures ${ }^{a}$

\begin{tabular}{lcccc}
\hline $\begin{array}{l}\text { Results measure } \\
\text { (dependent variable) }\end{array}$ & $\begin{array}{c}\text { Degrees } \\
\text { of } \\
\text { freedom }\end{array}$ & $\begin{array}{c}\text { Parameter } \\
\text { estimate for } \\
\text { independent variable: } \\
\text { partnership age }\end{array}$ & p-value & R-square \\
\hline $\begin{array}{l}\text { Completed floor space } \\
\text { improvements }\end{array}$ & 257 & $1,280,592$ & $<.0001$ & 0.0693 \\
$\begin{array}{l}\text { Completed plus } \\
\text { committed floor space } \\
\text { improvements }\end{array}$ & 257 & $2,001,081$ & $<.0001$ & 0.0813 \\
$\begin{array}{l}\text { Completed cost savings } \\
\begin{array}{l}\text { Completed plus } \\
\text { committed cost savings }\end{array}\end{array}$ & 257 & 262,408 & $<.0001$ & 0.0622 \\
\hline
\end{tabular}

${ }^{a}$ Based on simple regression analysis using partnership age as the independent variable.

this study. However, the relatively small R-Square values (ranging from 0.0622 to 0.0813) show that the age of partnership, by itself, accounted for less than one-twelfth of the variance in partnership results ${ }^{8}$.

\section{$\underline{\text { Average Office Rent }}$}

Average office rent was found to be positively related to three of the four results measures analyzed: completed plus committed floor space improvements; completed cost savings; and completed plus committed cost savings (Table 7). In other words, there tended to be greater achievement in those three results areas for partnerships located where the average office rent is relatively high. However, this finding should be treated with considerable caution because data were available for both average office rent and results for only 48 partnerships. Those respondents represent only about one-tenth of all Rebuild partnerships and all were located in major metropolitan areas, so the finding might not be applicable to the rest of the nation. Accordingly, it is prudent to say that the data suggest a possible relationship between partnership results and average office rent, but this study does not establish that definitively.

If there is an actual relationship between average office rent and partnership results, there are a few possible explanations for it. One possibility is that there is a greater incentive to take actions that save money on energy costs in areas where rents are

\footnotetext{
${ }^{8}$ The R-Square value indicates the amount of the variance in the dependent variable that is accounted for by the independent variable tested. Where R-Square is 0.08 , for example, $8 \%$ of the variance is explained by the independent variable in question.
} 
Table 7. Relationships between average office rent and four key results measures ${ }^{a}$

\begin{tabular}{lcccc}
\hline & \multicolumn{4}{c}{$\begin{array}{c}\text { Parameter } \\
\text { estimate for } \\
\text { independent }\end{array}$} \\
$\begin{array}{l}\text { Results measure } \\
\text { (dependent variable) }\end{array}$ & $\begin{array}{c}\text { of } \\
\text { freedom }\end{array}$ & $\begin{array}{c}\text { variable: average } \\
\text { office rent }\end{array}$ & p-value & R-square \\
\hline $\begin{array}{l}\text { Completed floor space } \\
\text { improvements }\end{array}$ & 47 & 90,643 & $\begin{array}{c}\text { NOT SIG. } \\
(0.268)\end{array}$ & 0.0266 \\
$\begin{array}{l}\text { Completed plus committed } \\
\text { floor space improvements }\end{array}$ & 47 & 478,491 & 0.021 & 0.1102 \\
$\begin{array}{l}\text { Completed cost savings } \\
\begin{array}{l}\text { Completed plus committed } \\
\text { cost savings }\end{array}\end{array}$ & 47 & 118,464 & 0.025 & 0.1045 \\
\hline \multicolumn{1}{c}{${ }^{a}$ Based on simple regression analysis using average office rent as the independent variable. } &
\end{tabular}

higher, because the felt need to control expenses is likely to be substantial. In this case, real estate expenses would actually be a causal factor influencing the number and type of Rebuild America actions that are taken. An alternative (non-causal) explanation is that there's more building space available to retrofit in the largest urban areas, where rents tend to be higher.

\section{Number of Projects per Partnership}

As shown in Table 8, there was a significant positive relationship between the number of projects per partnership and all four results measures that were analyzed. In other words, partnerships with more projects tended to achieve greater results, as hypothesized. It should be noted that two different sets of results measures were used in this analysis. When the independent variable being tested was the number of projects completed, completed floor space improvements and cost savings were used as the dependent variables. When the independent variable was all projects (completed plus committed), the dependent variables were completed plus committed floor space improvements and cost savings. The R-Square values shown in Table 8 indicate that the number of projects, by itself, accounted for between 5 and 11 percent of the variance in partnership results.

\section{Age of Partnership and Number of Projects per Partnership Combined}

Of the three significant independent variables discussed above, two of them-age of partnership and number of projects per partnership—-had non-missing values for enough partnerships to indicate that their inclusion in a multiple regression analysis was 
Table 8. Relationships between number of projects per partnership and four key results measures ${ }^{a}$

\begin{tabular}{|c|c|c|c|c|}
\hline $\begin{array}{l}\text { Results measure } \\
\text { (dependent variable) }\end{array}$ & $\begin{array}{l}\text { Degrees } \\
\text { of } \\
\text { freedom }\end{array}$ & $\begin{array}{c}\text { Parameter estimate } \\
\text { for independent } \\
\text { variable: number of } \\
\text { projects per } \\
\text { partnership } \\
\end{array}$ & p-value & R-square \\
\hline $\begin{array}{l}\text { Completed floor space } \\
\text { improvements }\end{array}$ & 257 & $1,011,373$ & $<.0001$ & 0.0743 \\
\hline $\begin{array}{l}\text { Completed plus } \\
\text { committed floor space } \\
\text { improvements }\end{array}$ & 257 & 836,249 & $<.0001$ & 0.1122 \\
\hline $\begin{array}{l}\text { Completed cost } \\
\text { savings }\end{array}$ & 257 & 182,985 & .0002 & 0.0520 \\
\hline $\begin{array}{l}\text { Completed plus } \\
\text { committed cost savings }\end{array}$ & 257 & 183,577 & $<.0001$ & 0.0915 \\
\hline
\end{tabular}

${ }^{a}$ Based on simple regression using number of projects per partnership as the independent variable. Number of completed projects is used in the analysis when the dependent variables are completed floor space improvements and cost savings. Number of completed plus committed projects is used when the dependent variables are completed plus committed floor space improvements and cost savings.

likely to yield reliable results. ${ }^{9}$ Table 9 shows that both of the independent variables remained significantly related to all four results measures in the presence of each other. This indicates that the effect of partnership age on performance was due to more than just an increase in the number of projects that might occur over time. Each factor-age and number of projects - exerted its own influence on program results and the amount of the variance accounted for by these two items in combination was substantially greater than for either one by itself. The strongest relationship found through this analysis was between the two independent variables and completed plus committed floor space improvements. In that case, partnership age and number of projects per partnership, in combination, accounted for nearly one-fifth of the observed variance in the results measure.

\section{PARTNERSHIP-REPORTED FACTORS RELATED TO GOOD PERFORMANCE}

Telephone interviews were conducted with representatives of 61 Rebuild America Partnerships. Among other things, the interviewees were asked to describe what they

\footnotetext{
${ }^{9}$ For the third significant independent variable — average office rent—-data were available for only 48 partnerships and it was feared that the findings resulting from a multiple regression analysis containing this variable would be non-representative and misleading.
} 


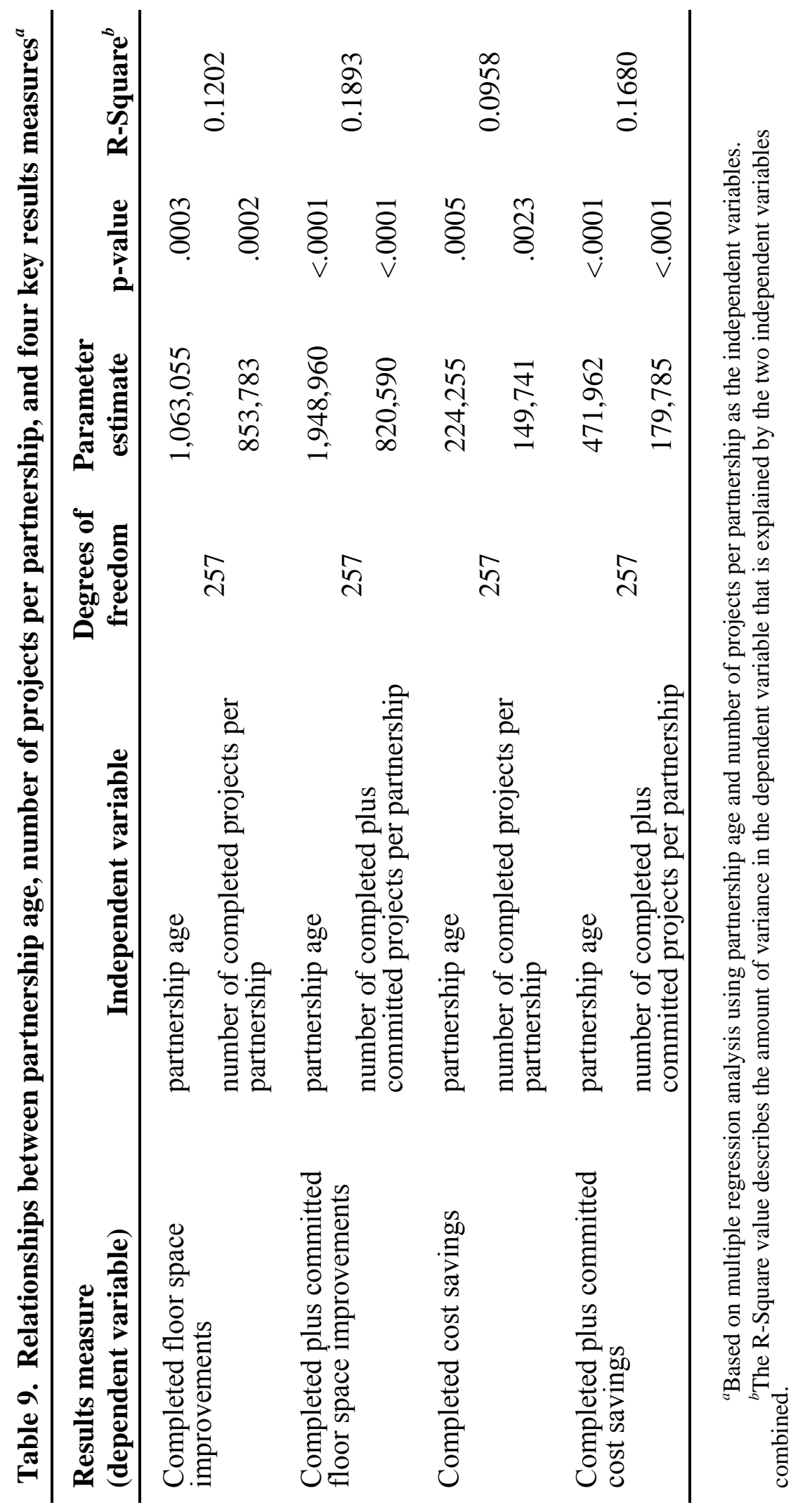


believed to be the most important factors influencing good performance by a partnership. Although the question was posed in an open-ended fashion, without any suggested responses or prompts, there was still a substantial amount of agreement among the respondents. The following items were mentioned by at least 10 interviewees as being very important to partnership success: general assistance from the Rebuild America representative; open communications among all partners; existence of a "champion" for the partnership; support from the relevant city or state government; effective marketing to attract new partners; strong community interest; quick return on investment; interaction with other community organizations; and continuity of funding. Each of these items is described in more detail below, and a listing of key factors mentioned by five or more respondents is presented in Table 10.

\section{General Assistance from Rebuild America Representative}

Almost half of those interviewed (29 respondents) stated that the general assistance and access to information provided by their Rebuild America representative ${ }^{10}$ was very important to the success of their program. Of the total number of respondents, 8 specified that help was provided by a Rebuild America regional representative, 7 said that help was provided by a Rebuild America state representative, 3 noted that help was provided by the Regional Team Leader, and 11 did not specify the Rebuild representative providing the assistance. A number of respondents mentioned that their representative responded very promptly to requests for help. Many of those interviewed revealed that they had close relationships with their representatives, and several noted that their representative always provided reliable assistance, regardless of the magnitude of the request. One respondent mentioned that when he asked for help, his representative would often pay him a personal visit the following day.

\section{Open Communications Among All Partners}

Similarly, almost half of the respondents (26) stressed the importance of open and active channels of communication among all participants. Sharing resources and relationship building were mentioned by some respondents as two positive outcomes of effective communication between partners. One interviewee stated that "active and dynamic relationships between partners" was very important. Other respondents noted the importance of good communication as a tool for evaluating and measuring progress by their many partners and projects. Another respondent said that good communication "provided an environment of cooperation and togetherness."

\footnotetext{
${ }^{10}$ A Rebuild America representative is a person affiliated with the Rebuild program who is responsible for helping individual partnerships identify their needs, access available resources, and obtain expert assistance.
} 
Table 10. Key factors influencing good performance, as reported

by partnership representatives

Key Factor

No. of

Responses

General assistance/support from Rebuild America representative

Open, active channels of communication among all partners within the partnership

Existence of a "champion" for the partnership

Support and involvement from relevant political entity (city or state)

Effective sales and marketing efforts of the partnership to recruit

partners ("selling the program"/ recruitment)

Community with strong interest in energy efficiency and the

environment

See payback/show a quick return on investment

Interaction/collaboration with other community leaders and

organizations at all levels

Continuity of funding

Ability to work together/teamwork/cooperation/flexibility among all partners within the partnership

Strategic coalition of partners

Follow through, one-on-one support, and "hand-holding" from the partnership to its partners

Effective program evaluations ("have we achieved our goals?") 7

$\begin{array}{ll}\text { Rapid provision of needed assistance } & 6\end{array}$

$\begin{array}{ll}\text { Reliable information on energy-saving opportunities } & 6\end{array}$

Concentration of efforts in small area to emphasize results $\quad 6$

$\begin{array}{ll}\text { Relationship building/patience/trust } & 6\end{array}$

Peer to peer exchanges 5

Continue to expand the partnership/keep it dynamic 5

Long-term partners with sustained involvement 5

Well-designed project plan with achievable goals 5 


\section{Existence of a "Champion"}

Thirty percent of those interviewed (19 respondents) believed that the existence of a "champion" (a strong leader and advocate for energy efficiency activities within the partnership) is important to program success. Respondents used words like dedicated, committed, and passionate to describe their champions. A few respondents described the right champion as "key to program success" and someone who "really cares." An important role of the champion, according to one interviewee, is to keep the program "alive and dynamic." Almost all of these respondents stressed the critical nature of the right champion and were very specific about the high standards and characteristics that individual must possess.

\section{Support from City or State Government}

Nineteen of those interviewed revealed that support and funding from city or state government were very important to the success of their program. In some cases it was essential, with one respondent describing it as critical to their existence. Many of the respondents expressed having "strong coalitions" with the agencies supporting them. Others noted that having support from the city or state government provided continuity for their programs and helped generate additional support from other organizations and the community. One respondent said that their state energy office was crucial in helping them "knock down barriers."

\section{Effective Marketing to Attract New Partners}

One-fourth of the respondents (15) described marketing as an important function of their partnership. Many described this marketing function as "selling the program" or "getting people on board." One marketing strategy revealed by several of those interviewed was to "lead by example" and to "show results." For example, some government offices took the lead by implementing retrofit measures in all their facilities to serve as a community example. Others started with small target areas to show the community and business leaders prompt results.

\section{$\underline{\text { Strong Community Interest }}$}

Thirteen interviewees stated that the interest and support they received from their community was an important determinant of partnership success. Many respondents described their communities as environmentally conscientious and supportive of energysaving efforts. One respondent said that their community had a "strong commitment to its environment." Several other respondents said that involved citizens helped them with "word-of-mouth" marketing and "grass-root" initiatives, which were important to the partnership's success. 


\section{Quick Return on Investment}

A quick return on investment was seen as an important factor of success by many respondents (12). Some respondents mentioned that when partners were involved in projects with timely results, they were more likely to continue with new projects, as well as help recruit new partners. In several cases, partnerships carefully chose projects that would show more immediate results as a strategy to recruit partners and add projects. One respondent noted the importance of trust and support from partners and the community and said that showing a quick return on investment helped achieve that.

\section{Interaction with Other Community Organizations}

Interaction with other community organizations was cited as an important factor influencing good performance by many of those interviewed (11 respondents). These respondents noted the importance of developing a network of people and organizations within their community. According to them, some of the benefits of such networks are teamwork, strategic relationships, publicity, and coalition building. Several respondents mentioned that it was important to communicate and be involved with many different groups, such as citizen organizations, business owners and elected officials.

\section{Continuity of Funding}

Ten of those interviewed contended that continuity of funding was very important to a successful partnership. Several respondents mentioned that when their initial funding was exhausted, their program ended. Those respondents expressed gratitude for the funding they did receive, but revealed feelings of frustration and disappointment when they were unable to continue their efforts. The same respondents also expressed the desire for more funding opportunities through the Rebuild America program.

\section{Other Responses}

The following factors were spontaneously mentioned as being important by between five and seven respondents: the ability to work together as a team with cooperation and flexibility among all partners; the strategic coalition of long-term partners; follow through, one-on-one support, and "hand-holding" from the partnership to its partners; effective program evaluations; rapid provision of needed assistance; reliable information on energy-saving opportunities; concentration of efforts in small areas to emphasize results; relationship building with patience and trust; peer to peer exchanges; continuing to expand the partnership and keep it dynamic; long-term partners with sustained involvement; and a well-designed project plan with achievable goals. 


\section{USEFUL PRODUCTS AND SERVICES}

As with the factors influencing good performance, there was substantial agreement among those interviewed concerning the kinds of assistance that they found to be most helpful. The following items were spontaneously mentioned by 10 or more respondents: tailored assistance from Rebuild America representative; general technical support; workshops and training sessions; assistance with networking; peer exchanges and interactions; access to staff and resources at national laboratories; help with marketing the benefits of Rebuild America; educational materials; Rebuild America website; links to national information sources; and financial support. Each of these is discussed below, and all responses given by five or more interviewees are shown in Table 11. In addition, there were a couple of frequently mentioned subjects addressed by

Table 11. Most useful types of resources provided by Rebuild America, as reported by partnership representatives

\begin{tabular}{lc}
\hline Type of Resource & No. of Responses \\
\hline $\begin{array}{l}\text { Individualized (tailored) assistance from Rebuild America employee or } \\
\text { contractor }\end{array}$ & 45 \\
General technical support & 26 \\
Workshops/training sessions & 25 \\
Assistance with networking & 18 \\
Peer exchanges and interactions & 16 \\
Access to staff and resources at national laboratories & 16 \\
Help with marketing the benefits of Rebuild America & 13 \\
Educational materials & 12 \\
Websites & 11 \\
Links to national information sources & 10 \\
Financial support & 10 \\
Access to conferences & 8 \\
RBA's "legitimizing their efforts"/RBA reputation/helping "sell the program" & 8 \\
Technical experts as guest speakers & 8 \\
Help with obtaining needed services & 7 \\
\hline "Partner Update" newsletter & 6
\end{tabular}


several different types of assistance (e.g., general technical support and peer exchanges both addressed the topic of potential energy-saving actions and opportunities) and these too are discussed.

\section{Tailored Assistance from Rebuild Representative}

Three-fourths of those interviewed (45 respondents) said that receiving individualized assistance tailored to their partnership's specific needs was very helpful to them. Many respondents mentioned their representative by name and revealed that a strong working and personal relationship had developed between them. It was common for interviewees to emphasize the dedication and commitment of their Rebuild America representative and to note the quality of the customer service provided and its timeliness. Specific types of tailored assistance mentioned by the respondents were technical advice, help with networking, providing answers to questions, help with research, and on-site visits. In one case, for example, the Rebuild America representative helped custom design an educational $\mathrm{CD}$ on engineering management for a partnership.

\section{General Technical Support}

Almost half of those interviewed (26 respondents) stated that the general technical support they received was very useful. It was also important to the respondents that the assistance was provided free of charge. Many respondents mentioned that the access to experts and technical information provided to them was very valuable. One respondent said that "we receive very targeted, high-level support." Specific types of support mentioned include help with: establishing procurement requirements when hiring contractors; understanding and preparing performance contracts; identifying financial aids and resources; conducting energy audits; reviewing architectural plans; understanding and applying specific types of retrofit measures; and obtaining information on alternative energy sources.

\section{Workshops/Training Sessions}

Workshops and training sessions were reported as very beneficial by almost half (25) of those interviewed. The educational benefits of the workshops and training sessions were mentioned by many of those respondents. Respondents also specified a number of ways in which Rebuild America provided assistance with workshops and training sessions, including: sending expert speakers; providing help with design and implementation; and hosting events.

\section{Assistance with Networking}

Of those interviewed, thirty percent (18 respondents) said that the networking opportunities provided were very important. These respondents cited many avenues available for networking through the Rebuild America program, such as contacting their 
representative, connecting with other partnerships, accessing the website, or attending the National Conference. All noted the importance of sharing information and utilizing other partnerships and projects as models. One respondent described the importance of networking as the "crucial link between those who have information and those who need it."

\section{Peer Exchanges and Interactions}

Close to thirty percent of interviewees (16 respondents) stated that the ability for partnerships to participate in peer reviews and exchanges was very beneficial.

Respondents noted that it served as a modeling tool and provided them with additional information resources. One respondent described peer exchanges as "great forums" for communication. They also were seen by some respondents as a way to build coalitions.

\section{$\underline{\text { Access to Staff and Resources at National Laboratories }}$}

Similarly, about thirty percent of those interviewed (16 respondents) mentioned that the link to national laboratories was a very useful service provided by the Rebuild America program, with some noting that these services were customized to their needs. One respondent described a situation in which he called his Rebuild America representative to get help with a specific problem and his representative checked all the labs in the United States associated with the Rebuild America program to see which was best suited to his particular need. The same respondent further described this service as a "great network of experts." Support with technical issues was mentioned by many respondents as the most utilized service from the labs. Others mentioned that they utilized the labs to conduct particular studies for them. One interviewee stated that the "technical assistance, the expertise, and the availability and breadth of knowledge provided by the labs was invaluable."

\section{Help with Marketing the Benefits of Rebuild America}

Thirteen of those interviewed mentioned that help with marketing and promoting the benefits of participation in the Rebuild America program was important. In one case, a respondent mentioned that his Rebuild America representative helped teach sales and marketing to his staff through training seminars. Another respondent mentioned that her partnership continued marketing efforts with Rebuild America's assistance even after their project had ended, to maintain community interest. This same respondent also mentioned the importance of promoting Rebuild America's association with the U.S. Department of Energy. According to this respondent, businesses were more likely to participate when they knew it was a nationally recognized program. Another respondent said that, for small towns, "national recognition fosters credibility." 


\section{$\underline{\text { Educational Materials }}$}

Twelve of those interviewed specified that the educational materials provided by the Rebuild America program were useful. One respondent stated that the "three key components of the Rebuild network were support, peer review, and education." Respondents also expressed the importance of the volume and variety of materials available to them. Several respondents noted that the booklets and information provided to them on Energy Smart Schools were very useful.

\section{Rebuild America Website}

The Rebuild America website was cited as a useful resource by eleven of those interviewed. Accessing of forms, technical assistance, email contacts, and other internet links were mentioned as services utilized on the website. Also, the Flash Report, an online newsletter highlighting partnership news and publicizing events, was noted as being very informative.

\section{Links to National Information Sources}

Ten interviewees stated that the links to national information sources were an important feature of the Rebuild America program. Of those, some specified the national laboratories, Rebuild America Strategic and Business Partners, and experts in particular fields as sources of information utilized. Others mentioned using these resources to obtain needed services or to assist in a hiring search for a contractor. One respondent described the link to national information sources as a "critical feature of the Rebuild America program."

\section{$\underline{\text { Financial Support }}$}

Many of those interviewed (10 respondents) stated that financial support from the Rebuild America program was very important to their efforts. In a few cases it was the sole reason the partnerships existed. Other respondents referred to the importance of financial aid in general but did not specifically mention monies available from the Rebuild America program. These respondents also mentioned a variety of services provided at no charge by the Rebuild America program, such as travel subsidies, aid with workshops and seminars, access to national information resources, and educational materials. It was not uncommon for respondents to characterize these services as "vital to their programs." One respondent revealed that the grant he received from the Rebuild America program helped him get his state agency's support to implement the program. Another interviewee described how important it was to receive information on various funding opportunities and resources. She also mentioned that her Rebuild America representative helped her obtain "non-biased critiques of different funding products." 


\section{Other Types of Resources}

The following items were spontaneously mentioned as being useful by between six and eight respondents: access to conferences; Rebuild America "legitimizing their efforts" and helping them "sell the program;" technical experts as guest speakers; help with obtaining needed services; and the Partner Update newsletter.

\section{$\underline{\text { Cross-Cutting Subject Areas }}$}

In addition to the useful Rebuild America resources described above, many respondents commented on the importance of two particular subject areas addressed by those resources: potential energy-saving actions and opportunities (11 respondents); and the savings potential of various actions (10 respondents). Several types of potential energy-saving actions and opportunities were mentioned, including: assistance with downtown revitalization projects; aid in conducting a needs assessment for a school district; and help with identifying and prioritizing projects. Regarding the savings potential of various actions, a few respondents mentioned bench marking and modeling approaches as two methods used to help identify savings. One partnership representative stated that Rebuild America was helping him by putting together a resource book on high performing energy-efficient schools. Another respondent noted that one of the most important services she had obtained from Rebuild America was information and tools on how to evaluate cost savings. 


\section{SUMMARY AND CONCLUSIONS}

In this chapter, we summarize the key findings reported previously and discuss their implications for the Rebuild America program.

\section{KEY FINDINGS}

Two hundred fifty-eight partnerships provided data on the results achieved by a total of 899 Rebuild America projects undertaken since the partnerships were formed. About three-fifths of those projects were classified as "committed" and two-fifths were "completed." Most partnerships were responsible for only a single project, and the majority of those with multiple projects had five or fewer. While there were a few very large projects, nearly all of the reported activity was of a much more moderate size.

The median value for the floor space improvements completed per partnership was a little less than 24,000 square feet for the full set of partnerships and almost 85,000 square feet for those partnerships that had been in existence for at least two years. For completed plus committed projects, the median number for the entire set of partnerships was approximately 580,000 square feet per partnership. For annual energy savings from completed projects, the median value was 345 million source BTUs per partnership for the entire data set and 992 million source BTUs for partnerships that were at least two years old. In contrast, the median value for annual energy savings for all projects (completed plus committed) was about 11.5 billion source BTUs per partnership. Median annual cost savings from completed projects were slightly less than $\$ 4,000$ per partnership for the full set of partnerships and over $\$ 15,000$ for those partnerships that had been formed at least two year previously. For committed and completed projects together, the median value for annual cost savings jumped to almost $\$ 146,000$ per partnership. The median energy efficiency investment was just over $\$ 17,000$ per partnership for the full set of completed projects and $\$ 107,000$ for the subset of partnerships that had been in existence two years or longer. For completed plus committed projects, the median investment was over $\$ 800,000$ per partnership. Clearly, the median value for each results measure for completed projects was higher for the subset of more mature partnerships. And for all projects (completed plus committed), the median values were much higher than for completed projects alone. This is largely because it takes new partnerships some time to start completing their planned projects and because many partnerships anticipate substantial accomplishments from their committed activities.

In combination, the responding partnerships reported over half a billion square feet of floor space improvements, over 9 trillion source BTUs of annual energy savings, over $\$ 130$ million of annual cost savings, and more than $\$ 600$ million in energy efficiency investments for all completed projects. For all projects (completed plus committed), the combined results were between two and three times the size of those 
achieved by completed projects alone. Specifically, slightly over one billion square feet of space was renovated, nearly 27 trillion source BTUs and over $\$ 300$ million were saved annually, and more than $\$ 1.5$ billion was invested in energy efficiency efforts. The actual results achieved by the Rebuild America program are almost certainly greater than those described here because over 200 partnerships did not report their projects' accomplishments. In addition, the reported annual energy and cost savings are expected to continue for many years.

According to the U.S. Department of Energy's recent Rebuild America 2002 report (2003), every federal dollar spent on the Rebuild program from its inception through the end of 2002 generated $\$ 9.38$ of energy-efficiency investment and $\$ 18.43$ in cumulative energy cost savings over time. In addition, the current study shows that each dollar of program funding has resulted in nearly 8 square feet of floor space improvements, \$1.95 in annual cost savings, and 0.134 million source BTUs in annual energy savings from completed projects. For all projects (completed plus committed) each dollar of program funding is associated with over 16 square feet of floor space improvements, \$4.41 in annual cost savings, 0.396 million source BTUs in annual energy savings, and \$22.35 in energy efficiency investment. As noted above, these numbers almost certainly undercount actual accomplishments because many Rebuild partnerships did not report their project results. Also, the annual energy and cost savings reported here are for a single year only, and can be expected to continue well into the future.

The greatest number of projects took place in the local and state government sector, followed by K-12 schools, commercial buildings, colleges/universities, and public/multi-family housing. Completed projects involving K-12 schools were far ahead of all the other sectors in terms of the median achievements for all results measures. For all projects (completed plus committed), K-12 schools reported the largest median values for floor space improvements and energy efficiency investment, while colleges/ universities led the way in terms of total annual energy and cost savings. Accomplishments for all projects combined, which depend on the number of projects carried out and the results achieved by each, were highest in K-12 schools for floor space improvements and in the local and state government sector for all other results measures.

Because of the very limited response to our request for primary data on partnership context and characteristics, we could test only a few hypotheses, primarily involving data that were available from secondary sources. From that limited statistical analysis, we found that partnership age and the number of projects per partnership were both positively related to all the results measures that we tested, by themselves and in the presence of each other. This means that those partnerships that had been in existence the longest and had the greatest number of projects tended to have improved the greatest number of square feet and achieved the greatest annual cost savings. Average office rent also was positively related to three of the four results measures tested (completed plus committed floor space improvements, completed cost savings, and completed plus committed cost savings), indicating that accomplishments were greatest in areas with 
higher property values. However, this finding should be treated as only suggesting a possible relationship and not clearly establishing it, since the number of respondents with the data necessary to run this analysis was quite small and probably not representative of the entire population of Rebuild partnerships.

Representatives of 61 Rebuild America partnerships were directly asked for their opinions on the most important influences on partnership performance and the most useful types of resources provided by the program. The factors most frequently mentioned as influencing good partnership performance were: general assistance from the Rebuild America representative; open communications among all partners; existence of a "champion" for the partnership; support from the relevant city or state government; effective marketing to attract new partners; strong community interest; quick return on investment; interaction with other community organizations; and continuity of funding.

The types of Rebuild America resources that were most frequently mentioned as being most helpful were: tailored assistance from a Rebuild America representative; general technical support; workshops and training sessions; assistance with networking; peer exchanges and interactions; access to staff and resources at national laboratories; help with marketing the benefits of Rebuild America; educational materials; Rebuild America website; links to national information sources; and financial support. In addition, many respondents commented on the importance of two particular subject areas addressed by those resources: potential energy-saving actions/opportunities and the savings potential of various actions.

\section{CONCLUDING DISCUSSION}

The description of combined results presented above shows that the Rebuild America program has completed very substantial floor space improvements in public facilities, commercial buildings, and multifamily housing units, which are associated with abundant — and cost-effective — annual energy and cost savings and a considerable investment in energy-efficient projects. And the results from committed projects are expected to be even greater than those achieved to date.

Not surprisingly, observed results tended to be greatest for those partnerships that had been in existence the longest and had the greatest number of projects. This makes sense because such partnerships have had the largest number of opportunities to achieve results as well as the most time to establish the necessary organizational and financial relationships, acquire needed resources and expertise, and implement effective energysaving projects. Furthermore, it should be noted that many of the factors reported by partnerships as being related to good performance (e.g., assistance from a program representative, communication among partners, interaction with other community organizations) and the resources identified as being most useful (e.g., technical support, workshops and training sessions, assistance with networking, educational materials) are 
very consistent with the "program logic" for Rebuild America presented in the introductory chapter. That logic model asserts that the technical information, assistance, training, and peer exchanges provided through the community partnership structure lead to the increased use of energy-efficient technologies.

Clearly, the Rebuild program has been successful in encouraging the adoption of energy efficiency measures and practices in targeted buildings, and the effects of the program are sure to continue, both from projects that have been initiated to date and from new projects that are likely to be implemented in the future.

Based on the previously-discussed findings, we suggest the following possible activities for sustaining and building upon the past successes of the Rebuild America program:

- $\quad$ Keep providing individualized assistance, technical support, and training to partnerships, in a timely manner;

- $\quad$ Provide training on key topics to state and regional Rebuild representatives, so that they can best serve the partnerships. Important topics for training include: information on energy-savings opportunities and techniques; procedures for marketing the program and recruiting partners; methods for establishing and maintaining good communications among partners and with other community organizations; and the development of project plans and goals.

- Have the most effective Rebuild America representatives provide the abovementioned training for the other representatives;

- Ensure that sufficient informational materials are available regarding those sectors that are most frequently served and have yielded the greatest results (i.e., local/state government, K-12 schools, commercial buildings);

- $\quad$ Facilitate peer-to-peer exchanges among Rebuild America partners;

- Encourage active partnerships to stay in operation, because the number of completed projects and all results measures tend to increase with time;

- $\quad$ Encourage partnerships to take on additional projects, because this is associated with greater results and sustains program efforts;

- $\quad$ Encourage partnerships to report their activities, to allow more complete tracking of results; and, finally,

- $\quad$ Contact partnerships that report no completed projects after three years to see if there are any readily-available resources that Rebuild America could provide to allow them to move to project completion. Such contact could also be used to determine if a partnership has become dormant and might need less active support and assistance. Resources permitting, the same type of contact could be made with those partnerships that have never reported project results. 


\section{ACKNOWLEDGMENTS}

We would like to acknowledge the contributions of a number of people who contributed to this report and the study on which it is based. Vicki Norberg-Bohm of Harvard University's Science, Technology, and Public Policy Program and Gretchen Jordan of Sandia National Laboratories provided valuable advice on research design issues. Staff at the U.S. Department of Energy's Regional Offices - Greg Andrews in Atlanta, Carla Clemons in Chicago, Greg Davoren in Boston, Susan Guard in Philadelphia, Richard Putnam in Seattle, and David Waltzman in Denver-also provided useful advice during the study and were especially important in facilitating the collection of data from key individuals at Rebuild America partnerships. Scott Igoe, Michelle Clark, and Dennis Clough at Aspen Systems Corporation provided, and helped explain, important results data from the Rebuild partnerships. Representatives from 61 partnerships gave us detailed information on the most important factors influencing good performance and the most valuable resources offered by the Rebuild program. Dan Sze and Jerry Dion of the U.S. Department of Energy provided valuable input throughout the study and also offered insightful comments on the draft report. Additional valuable feedback on the draft report was provided by Gretchen Jordan, Jeff Brown of Aspen Systems, and three ORNL colleagues: Marilyn Brown, Ron Shelton, and Bruce Tonn. Finally, Karen Bowman and Tracy Bodine at ORNL assembled the report and provided substantial support throughout the process. 


\section{REFERENCES}

National Climatic Data Center, 2002a. Normal Monthly Cooling Degree Days (base 65), National Oceanic and Atmospheric Administration. http://lwf.ncdc.noaa.gov/oa//climate/online//ccd/nrmcdd.html

National Climatic Data Center, 2002b. Normal Monthly Heating Degree Days (base 65), National Oceanic and Atmospheric Administration. http://lwf.ncdc.noaa.gov/oa//climate/online//ccd/nrmhdd.html

National Climatic Data Center, 1993a. Historical Climatology Series 5-1; State, Regional, and National Monthly and Seasonal Heating Degree Days Weighted by Population (1990 Census), July 1931 - June 1992, National Oceanic and Atmospheric Administration.

National Climatic Data Center, 1993b. Historical Climatology Series 5-2; State, Regional, and National Monthly and Annual Cooling Degree Days Weighted by Population (1990 Census), January 1931 - December 1991, National Oceanic and Atmospheric Administration.

Powers, Mel, 2000. The Action Plan: Your Blueprint for Success. U.S. Department of Energy, October.

Reis, Inc., 2002. Metropolitan Region Office Market Overview, Average Asking Rent, http://www.rebuz.com/Markets.htm

U.S. Department of Energy, 1996. Rebuild America's Community Partnership Handbook, Washington, DC.

U.S. Department of Energy, 2001. Rebuild America Strategic Plan 2001-2010, Office of Energy Efficiency and Renewable Energy, Washington, DC.

U.S. Department of Energy, 2002a. Find a Partnership. www.rebuild.org/partnerships/cp_find.asp

U.S. Department of Energy, 2002b. Rebuild America 2001, DOE/EE-0268. Office of Energy Efficiency and Renewable Energy, Washington, DC.

U.S. Department of Energy, 2003. Rebuild America 2002. Office of Energy Efficiency and Renewable Energy, Washington, DC.

U.S. Energy Information Administration, 2001. State Energy Price and Expenditure Report 1999, U.S. Department of Energy, Washington, DC. www.eia.doe.gov/emeu/states/sep sum/html/rank pr.html 


\section{INTERNAL DISTRIBUTION}

1. M. A. Brown

2. J.E. Christian

3. T.R. Curlee

4. S.G. Hildebrand

5. P.J. Hughes

6. G.K. Jacobs
7. J.M. MacDonald

8-17. M. Schweitzer

18-22. R. L. Shelton

23. B.E. Tonn

24. Central Research Library

25. ORNL Laboratory Records-RC

\section{EXTERNAL DISTRIBUTION}

26. Ted Alexander, Rebuild Shelby, P.O. Box 2042211 South Trade Street, Shelby, NC 28151-2042

27. Greg Andrews, U.S. Department of Energy, 75 Spring Street, Suite 200, Atlanta, GA 30303

28. Manny Anunike, Ohio Department of Development, 77 South High Street, Floor 26, P.O. Box 1001, Columbus, OH 43216-1001

29. Margo Appel, EE-2K/Forrestal Building, U.S. Department of Energy, 1000 Independence Ave. S.W., Washington, DC 20585

30. Mark Bailey, EE-2K/Forrestal Building, U.S. Department of Energy, 1000 Independence Ave. S.W., Washington, DC 20585

31. Norman Bair, Wisconsin Energy Bureau, P.O. Box 7868, Madison, WI 53707-7868

32. Ken Baker, Aspen Systems Corporation, 1301 North Orchard Street, Boise, ID 83706

33. Richard Baldauf, South Carolina Energy Office, 1201 Main Street, Suite 820, Columbia, SC 29201

34. Doug Baston, Northeast by Northwest, 18 Sheepscot Road, Alna, ME 04535

35. Jay Beeks, Oregon Parks and Recreation Department, 1115 Commercial Street, NE, Suite 1, Salem OR 97301-1002

36. Perry Been, Texas Energy Office, 111 E. $17^{\text {th }}$ St., Austin, TX 78701

37. Toby Benson, State of Montana, Department of Environmental Quality, 1520 East 6th Avenue, Helena, MT 59620-0901

38. Wendel Bigham, Meridian District \#2, 911 N. Meridian Rd., Meridian, Idaho 83642

39. Kirk Bond, Aspen Systems Corporation, 7815 North Adrian Avenue, Kansas City, MO 64151-8202 
40. Jeff Brown, Aspen Systems Corporation, 241 West Washington Street, Nashville, NC 27856

41. Darrell Buffaloe, Idaho State University, P.O. Box 8137, Pocatella, ID 83209

42. Isabell Burger, Western NY Energy Smart Communities, 95 Franklin St., Room 1077, Buffalo, NY 14202

43. Gene Bustamante, City of Albuquerque, 1801 Fourth St., Building B, Albuquerque, NM 87102

44. Jennifer Chiodo, Vermont Energy and Investment Corporation, 255 South Champlain Street, Burlington, VT 05401

45. Kim Christianson, State of North Dakota, Division of Community Services, 600 East Boulevard, State Capitol, 14th Floor, Bismark, ND 58505-0170

46. Heather Clark, NYSERDA, 17 Columbia Circle, Albany NY 12203

47. Carla Clemons, U.S. Department of Energy, One South Wacker Drive, Suite 2380, Chicago, IL 60606-4616

48. Dennis Clough, 14 Wrightson Ave., Easton, MD 21601

49. Ed Cobham, Florida Department of Community Affairs, 2555 Shumard Oak Boulevard, Tallahassee, FL 32399-2100

50. Patrick Condon, Rhode Island State Energy Office, One Capitol Hill, Providence, RI 02908

51. Sharon Cooke, District of Columbia Energy Office, 2000 14th Street NW, Suite 300 East, Washington, DC 20009

52. Cheryl Crawley, 1413 E. $12^{\text {th }}$ Street, The Dalles, Oregon 97058

53. Benjamin Dadd, Coastal Community Action, Inc., P.O. Box 1007475, U..S. Highway 70 West, Havelock, NC 28532

54. Cyane Dandridge, Strategic Energy Innovations, 175 North Redwood Drive, Suite 150, San Rafael, CA 94903

55. Darin Davidson, Corvallis School District, P.O.Box 3509J, Corvallis, OR 97339

56. Greg Davoren, U.S. Department of Energy, JFK Federal Building, Suite 675, Boston, MA 02203-0002

57. Frank DeMarchi, Daytona Beach Partnership, 100 South Beach Street, Daytona Beach, FL 32114

58. Julie Dhatt-Honekamp, Spokane Neighborhood Action Program, 2116 E. First Ave., Spokane, WA 99202

59-78. Jerome Dion, EE-3B/Forrestal Building, U.S. Department of Energy, 1000 Independence Ave., S.W., Washington, DC 20585

79. Jim Dombrosk, University of New Hampshire, 17 Leavitt Lane, Durham, NH 03824

80. Terry Ellis, Tennessee Department of Economic and Community Development, Rachel Jackson Building, 320 Sixth Avenue North, 6th Floor, Nashville, TN 37243-0405

81. Skeet Fitzgerald, Neighborhood Services, City of Henderson, 240 Water Street, Henderson, NV 89015 
82. Deyanira Flores, Rebuild Clark County, 500 S. Grand Central Parkway, Las Vegas, NV 89155-1712

83. Bob Friedman, Duke University, 200 Facility Center, Durham, NC 27708

84. Rebecca Garrett, Alaska Energy Authority, 813 West Northern Lights Boulevard, Anchorage, AK 99503

85. Mike Glenn, Utah Energy Office, 1594 West North Temple, Suite 3610, P.O. Box 1406480, Salt Lake City, UT 84114-6480

86. Patrick Griffiths, Deschutes County, 575 N.E. $15^{\text {th }}$ Street, Bend, OR 97701

87. Susan Guard, U.S. Department of Energy, 100 Penn Square East, Suite 890, The Wanamaker Building, Philadelphia, PA 19107-3396

88. Cindy Gunn, Aspen Systems Corporation, 3 Ledge Circle, Concord, NH 03301

89. Steve Harding, State of South Dakota, 711 East Wells Avenue, Pierre, SD 57501-3369

90. Vicki Heidinger, Rebuild Asheville, 25 Gaston St., Asheville, NC 28801

91. Bob Henderson, Center for Energy and Environment, 211 N. First St., Suite 455, Minneapolis, MN 55401

92. Martha Hewett, Center for Energy and Environment, 211 N. First St., Suite 455, Minneapolis, MN 55401

93. Deborah Hill, Aspen Systems Corporation, 241 West Washington Street, Nashville, NC 27856

94. Lois Jackson, State of Vermont, Energy Efficiency Division, 112 State Street, Drawer 20, Montpelier, VT 05620

95. Gretchen Jordan, Sandia National Laboratories, 950 L'Enfant Plaza, SW, Suite 110, Washington, DC 20084

96. Nick Keller, Aspen Systems Corporation, 2277 Research Blvd., MS 6Z, Rockville, MD 20850

97. Linda King, Aspen Systems Corporation, 1229 SW Creston Avenue, Des Moines, IA 50315

98. Glen Kizer, Foundation for Environmental Education, P.O. Box 340581, Columbus, $\mathrm{OH} 43234$

99. Michelle Knapik, Rebuild Philadelphia, 1401 JF Kennedy Blvd., Suite 1000, Philadelphia, PA 19102

100. Peter Konesky, State of Nevada, Department of Business and Industry, 727 Fairview Drive, Suite F, Carson City, NV 89701

101. Kelly Launder, Michigan Department of Consumer and Industry Services, 6545 Mercantile Way, Suite 9, Lansing, MI 48909

102. Pat LeDonne, EE-2K/Forrestal Building, U.S. Department of Energy, 1000 Independence Ave. S.W., Washington, DC 20585

103. Allyn Lee, City and County of Honolulu, 650 S. King St., Honolulu, HI 96813

104. Lilly Lee, City of East Palo Alto, 2415 University Avenue, $2^{\text {nd }}$ Floor, E. Palo Alto, CA 94303

105. Greg Lenaghan, Illinois Department of Commerce and Community Affairs, 620 East Adams Street, Springfield, IL 62701-1615

106. Dave Logan, Ada County Operations, 200 W. Front St., Boise, ID 83702 
107. Bernell Loveridge, Utah Energy Office, 1594 West North Temple \# 3610, Salt Lake City, UT 84114-6480

108. Kim Lundgren, City of Medford, 85 George P. Hassett Drive, Room 304, Medford, MA 02155

109. Clarence Mann, Alabama Department of Economic and Community Affairs, 401 Adams Avenue, Montgomery, AL 36104

110. Kenneth Manning, East San Gabriel Valley Partnership, 1501 W. Del Norte Street, West Covina, CA 91790

111. Craig Marks, Arizona Department of Commerce, 1700 W. Washington, Suite 220, Phoenix, AZ 85007

112. Susan Marx, Brevard Public Schools, 1254 S. Florida Ave., Rockledge, FL 32955

113. Jim Maskrey. Hawaiian Electric Co. Inc. - Energy Solutions, 220 S. King St., Suite 1010, P.O. Box 2750, Honolulu, HI 96840

114. Jennifer May, Potomac Communications Group, 2025 M Street NW, Suite 350, Washington, DC 20036

115. Louis McArthur, Louisiana State Energy Office, P.O. Box 44156, 617 N. Third St., Baton Rouge, LA 70802

116. Eileen McHugh, State of Massachusetts, 70 Franklin Street, 7th Floor, Boston, MA 02110-1313

117. Jim McTish, Pennsylvania Department of Environmental Protection, 555 North Lake, Suite 6010, Conshohoken, PA 19428

118. Betty Merrill, Oregon Energy Office, 625 Marion Street NE, Salem, OR 97301-3742

119. Karen Messmer, Washington State University, 925 Plum Street SE, Building 4, Olympia, WA 98504-3165

120. John Millhone, EE-2K/Forrestal Building, U.S. Department of Energy, 1000 Independence Ave. S.W., Washington, DC 20585

121. Bill Mixon, TECH Support Services, 310 Timberline Drive, Kingston, TN 37763

122. Judy Monier, Oakland Housing Authority, 1619 Harrison St., Oakland, CA 94612

123. John Morrill, Arlington County Government, 1400 N. Uhle St., \#403, Arlington, VA 22201

124. Cynthia Moseley, North Carolina Department of Commerce, Energy Division, 1340 Mail Service Center, Raleigh, NC 27699

125. Christina Mudd, Maryland Energy Office, 1623 Forest Drive, Annapolis, MD 21403

126. Mike Myers, Aspen Systems Corporation, 2624 Neimann Drive, Austin, TX 78748

127. Alan Nagle, Aspen Systems Corporation, 1617 Cole Boulevard, MS 1521, Golden, CO 80401-3393

128. Vicki Norberg-Bohm, Belfer Center for Science and International Affairs, 20 University Road 554, 179 JFK Street, Cambridge, MA 02138

129. John Nunley III, Wyoming Business Council, 214 West 15th Street, Cheyenne, WY 82002 
130. Annette Osso, Virginia Housing and the Environmental Network, P.O. Box 6539, Arlington, VA 22206

131. Bob Painter, Missouri Department of Natural Resources, 4750 Troost, Kansas City, MO 64166

132. Terry Pease, State of Wisconsin, Department of Administration, 101 East Wilson Street, 6th Floor, Madison, WI 53703

133. Vince Pedicini, New Jersey Board of Public Utilities, Two Gateway Center, 9th Floor, Newark, NJ 07102

134. Matt Pesce, Aspen Systems Corporation, 4414 Galleria Pointe Circle, Rock Hill, SC 29730

135. Pat Peyton, City of Centerville, 314 E. Maple, Centerville, IA 52544

136. Jim Ploger, Kansas Corporation Commission, 1500 Southwest Arrowhead Road, Topeka, KS 66604-4027

137. Melvin Powers, Aspen Systems Corporation, 241 West Washington Street, Nashville, NC 27856

138. Richard Putnam, U.S. Department of Energy, 800 5th Street, Suite 3950, Seattle, WA 98104

139. Elizabeth Raman, Hawaii Department of Business, Economic Development and Tourism, P.O. Box 2359, Honolulu, HI 96804

140. John Root, Rebuild Muscatine, Iowa, 3205 Cedar Street, Muscatine, Iowa 52761

141. John Ruckes, Connecticut State Energy Office, 450 Capital Avenue, MS 52ENR, Hartford, CT 06106-1308

142. Fred Schwartz, City/County of San Francisco, 1155 Market St., $4^{\text {th }}$ Floor, San Francisco, CA 94103

143. Sue Seifert, Idaho Department of Water Resources, 1301 North Orchard, Boise, ID 83706

144. Ann Selzer, Nebraska Energy Office, 1111 O Street, Suite 223, Lincoln, NE 68509-5085

145. Willis Shawver III, Covington School Board, 340 E. Walnut St., Covington, VA 24426

146. Elizabeth Shirakh, California Energy Commission, 1516 9th Street, MS 26, Sacramento, CA 95814

147. Fred Sisine, Library of Congress, 101 Independence Ave., SE, Washington, DC 20540

148. Jennifer Slusarz, Rebuild Sarasota County, Facilities Maintenance Division, $473017^{\text {th }}$ St., Sarasota, FL 34235-8201

149. Brevan Smith, Virgin Islands Energy Office, 200 Strand Street, Fredericksted, VI 00840

150. Linda Smith, Governor's Office of Energy Management and Conservation, 225 East 16th Avenue, Suite 650, Denver CO 80203

151. John Snell, Rebuild Boston, 151 Merrimac Street, Boston, MA 02114

152. Rebecca Spiess, Iowa Department of Natural Resources, 502 East 9th, Des Moines, IA 50319 
153. Julie Stephens, Rebuild Central New Mexico, 1801 Fourth St. NW, Building B, Albuquerque, NM 87102

154. Kirk Stone, New Hampshire Office of Energy and Community Service, 57

Regional Drive, Suite 3, Concord, NH 03301

155-174. Dan Sze, EE-2K/Forrestal Building, U.S. Department of Energy, 1000 Independence Ave. S.W., Washington, DC 20585

175. Dub Taylor, Texas State Energy Conservation Office, LBJ State Office Building, 111 East 17th Street, Room 1114, Austin, TX 78774

176. Harold Trujillo, New Mexico Department of Energy, Minerals, and Natural Resources, P.O. Box 1948, Santa Fe, NM 87505

177. Verlina Underwood, Mississippi Development Authority, State Energy Division, P.O. Box 849, Jackson, MS 39205

178. Barry Vesser, North Fork Community Development Council, Inc., P.O. Box 1484, North Fork, CA 93643

179. Gus Villaret, University Housing and Dining Service, 102 Buxton Hall, Oregon State University, Corvallis, OR 97331

180. Virginia Waik, City of Palo Alto, 250 Hamilton Ave., P.O. Box 10250, Palo Alto, CA 94303

181. Dave Waltzman, U.S. Department of Energy, 1617 Cole Boulevard, MS 1521, Golden, CO 80401

182. Scott Wentworth, City of Oakland, 7101 Edgewater Drive, Oakland, CA 94621-3001

183. Jim Westberg, Arizona Department of Commerce, State Energy Office, 3800 North Central Avenue, Suite 1400, Phoenix, AZ 85012

184. Quentin Wiest, Bergen County Improvement Authority, One Bergen County Plaza, Room 333, Hackensack, NJ 07601

185. Gavin Williams, Indiana Department of Commerce, One North Capitol, Suite 700, Indianapolis, IN 46204

186. Michael Williams, Stark Metropolitan Housing Authority, 400 East Tuscarawas Street, Canton, OH 44702-1131.

187. Bill Willis, West Virginia Development Office, State Capitol Complex, Building 6, Room 645, Charleston, WV 25305

188. Patrick Wolf, Rebuild Portland Public Schools, P.O. Box 3107, Portland, OR 97208-3107

189. Eileen Yoshinaka, U.S. Department of Energy, P.O. Box 50168, 300 Ala Moana Boulevard, Room 4-131, Honolulu, HI 96850

190. Charles Young, Aspen Systems Corporation, 241 West Washington Street, Nashville, NC 27856

191. Geoff Young, Kentucky Department for Natural Resources, Division of Energy, 663 Teton Trail, Frankfort, KY 40601

192. Maynard Young, Hawaii Community Colleges, 4303 Diamond Head Road, Manele Building, Room 103, Honolulu, HI 96816 